\title{
A Self-Immolative Molecular Beacon for Amplified Nucleic Acid Detection
}

Magdalena Roth, Oliver Seitz

Submitted date: 11/05/2021 - Posted date: 12/05/2021

Licence: CC BY-NC-ND 4.0

Citation information: Roth, Magdalena; Seitz, Oliver (2021): A Self-Immolative Molecular Beacon for Amplified Nucleic Acid Detection. ChemRxiv. Preprint. https://doi.org/10.26434/chemrxiv.14573712.v1

Fluorogenic hybridization probes allow the detection of RNA and DNA sequences in homogeneous solution. Typically, one target molecule is activating the fluorescence of a single probe molecule. This limits the sensitivity of nucleic acid detection. Herein, we report a self-immolative Molecular Beacon (iMB), which escapes the one-target-one-probe dogma. The iMB probe includes a photoreductively cleavable $\mathrm{N}$-alkylpicolinium (NAP) linkage within the loop region. A fluorophore at the 5 '-end serves, on the one hand, as a reporter group and, on the other hand, as a photosensitizer of a NAP-linker cleavage reaction. In the absence of a target, the iMB adopts a hairpin shape. Quencher proups prevent photo-induced cleavage. The iMB opens upon hybridization with target, and both fluorescent emission as well as photo-inductive cleavage of the NAP-linker can occur. In contrast to previous chemical amplification probes, iMBs are unimolecular. Cleavage leads to products that have lower target affinity than the probes before reaction. Aided by catalysis, the method allowed the detection of 5 pM RNA target within 100 min.

File list (2)

iMB_Roth_Seitz.pdf (380.86 KiB)

view on ChemRxiv - download file

iMB_Roth_Seitz_SI.pdf (1.09 MiB)

view on ChemRxiv - download file 


\title{
A self-immolative molecular beacon for amplified nucleic acid detection
}

\author{
Magdalena Roth and Oliver Seitz*
}

Institute of Chemistry, Humboldt-Universität zu Berlin, Brook-Taylor-Str. 2, 12489 Berlin (Germany), E-mail: oliver.seitz@chemie.hu-berlin.de

Abstract: Fluorogenic hybridization probes allow the detection of RNA and DNA sequences in homogeneous solution. Typically, one target molecule is activating the fluorescence of single probe molecule. This limits the sensitivity of nucleic acid detection. Herein, we report a self-immolative Molecular Beacon (iMB), which escapes the one-target-one-probe dogma. The iMB probe includes a photoreductively cleavable $N$-alkyl-picolinium (NAP) linkage within the loop region. A fluorophore at the 5'-end serves, on the one hand, as a reporter group and, on the other hand, as a photosensitizer of a NAP-linker cleavage reaction. In the absence of target, the iMB adopts a hairpin shape. Quencher groups prevent photo-induced cleavage. The iMB opens upon hybridization with target, and both fluorescent emission as well as photo-reductive cleavage of the NAP-linker can occur. In contrast to previous chemical amplification probes, iMBs are unimolecular. Cleavage leads to products that have lower target affinity than the probes before reaction. Aided by catalysis, the method allowed the detection of 5 pM RNA target within 100 min. Measurements in cell lysate and RNA extract point to the robustness and sequence specificity of the template-triggered photoimmolation

Probe molecules that fluoresce upon recognition of specific nucleic acid targets are invaluable tools for applications in cell biology, biotechnology and molecular diagnostics. Molecular beacons (MBs) (Figure 1A) are a prime example of such turn-on signaling probes.[1] MBs and related probes[2] do not require enzymes and can, therefore, be applied in various settings from in vitro to in vivo scenarios. By design, MB probes adopt a hairpin structure, formed upon intramolecular hybridization of self-complementary stem units. This arranges a quencher in the immediate vicinity of the fluorophore. In the absence of target, the fluorescence is low. Hybridization of a target with the loop segment disrupts the stem, separates the two dyes and restores fluorescence. A host of MB modifications have been introduced with the aim to improve target specificity and the fold fluorescence enhancement.[3] However, without added enzymes a MB probe remains bound to the target and, as a result, the fluorescence enhancement will be low when probes are present in large excess of target; for example, when concentration of the nucleic acid target in a biological sample is low.

Chemical amplification methods provide a solution to the one-target-activates-one-probe issue.[4] In a typical scenario, annealing of two or more reactive oligonucleotide conjugates on the target triggers a proximity-induced chemical reaction that activates fluorescence emission. The existing chemical reaction systems belong to one of three categories; 1 ) ligation reactions, 2) functional group interconversions or 3 ) reactions that are catalyzed upon alignment of metal ligands with the aid of a template. Though high sensitivities in the picomolar range have been reported for reactive probes, several hours of reaction are normally required to accumulate signal.[5] 
A)

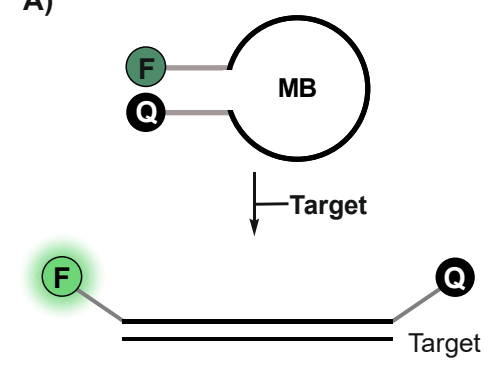

Q: 3xBMN535

F:<smiles>C=CCOC(=O)c1cc2cc3c(cc2oc1=O)N1CCCC(C)(CC(C)=O)CC1CC3C</smiles>

$X-Y$ :<smiles>CCCNC(=O)CCCC(=O)Nc1ccc(O)cc1</smiles>

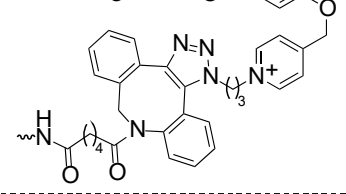

B)
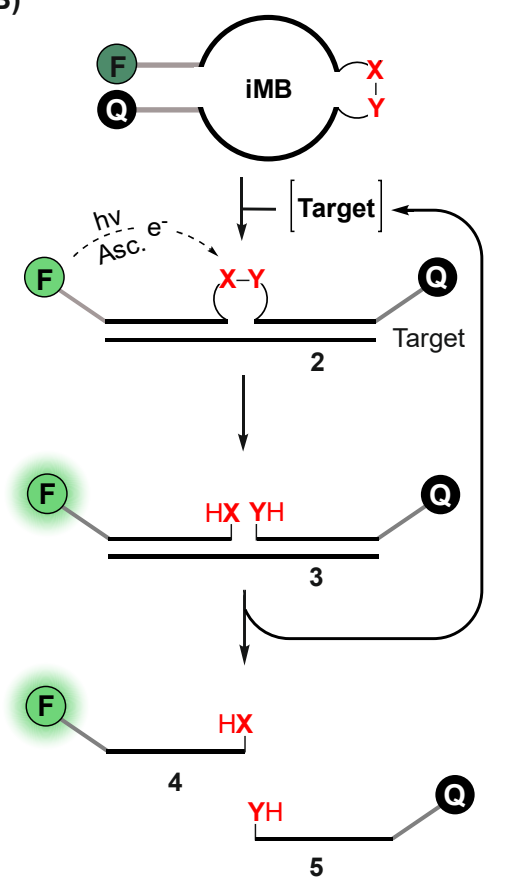<smiles>O=C1OC2C(F)CC(O)C(O)C2OC(=O)C1O</smiles>

(1)

$\mathbf{R}_{1}:{ }^{3} \mathbf{Q}^{\prime}-\underline{G A G} \underline{G T G}$ GTA GTT ATT-NH-CO- $\left(\mathrm{CH}_{2}\right)_{4}$-CO-N-Triazol- $\mathrm{C}_{3} \mathrm{H}_{6^{-}}$

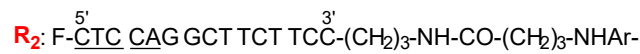

Figure 1. Comparison between the mechanisms of fluorescence signalling by A) a traditional Molecular Beacon and B) a selfimmolative Molecular Beacon iMB). A scissile unit X-Y (e.g. the depicted $N$-alkylpicolinium (NAP) linker) enables dye (F)sensitized iMB cleavage under the control of nucleic acid target. The target (RNA-strand) is being recycled after the photolysis and a new iMB can bind. C) Proposed mechanism of photoreductive NAP-phenol ether cleavage ${ }^{[10]}$. Underlined nucleotides indicate the MB stem unit.

The reported reaction systems typically involve the interplay and optimization of two or even more functionalized oligonucleotides. We envisioned a unimolecular, MB-like probe that allows the sensitive detection of nucleic acids in homogenous phase without added reagents or enzymes. To escape the one-target-activates-one-probe dogma, the unimolecular probe must undergo a cleavage reaction leading to product fragments that have a lower affinity for the target than the probe before reaction. Under these conditions, multiple reactions can proceed on a single target, hence enabling a catalytical chemical signal amplification.

We herein introduce self-immolative molecular beacon (iMB) probes, which include a photocleavable linker unit within the loop-region (X-Y in Figure $1 B)$. The cleavage reaction is catalyzed by a fluorophore such as the coumarin $\mathbf{1}$ which serves on the one hand as a reporter group and on the 
other hand as a photosensitizer of the cleavage reaction. Analogously to conventional MBs, the iMB probe is envisioned to adopt a hairpin shape in absence of target. This positions a quencher in vicinity of the fluorophore. Accordingly, fluorescence and also photosensitizing activity remain low. Target binding separates the fluorophore from the quencher $(\rightarrow 2)$. This restores fluorescence and activates the fluorophor's ability to photosensitize cleavage. The ternary complex formed upon cleavage has lower target affinity than the iMB probe prior cleavage. The product complex 3 can dissociate and the target will be able to act as a catalyst with little interference from product inhibition commonly observed in known templated reactions.

The photocleavable linker is the key unit of the iMB design. Fast photocleavage reactions have been reported for the $\mathrm{N}$-alkyl-picolinium (NAP) protecting group.[6] Falvey showed that [Ru(bpy)3]2+ complexes are efficient photocatalysts of reductive cleavage.[7] Winssinger applied the method for the DNA template-controlled liberation of NAP-caged fluorophores.[8] Falvey also reported liberation of amino acids and phosphates from NAP esters using high wavelength laser dyes acting as photosensitizers.[9] The metal-free photorelease reactions were performed in organic solvents. In test reactions, we dissolved a NAP-protected phenol in an aqueous buffer containing $10 \mathrm{mM}$ ascorbate as reductant and the ATTO425 (1) dye as photosensitizer (Figure S11). Gratifyingly, irradiation with a $455 \mathrm{~nm}$ blue LED induced efficient cleavage, also in the aqueous environment. As previously suggested, a likely cleavage mechanism involves a single electron transfer step from ascorbate 6 to the dye's excited state and from there to the electrophilic NAP group 8 (Figure 1C).[10] The resulting pyridine radical 9 then expells the phenolate leaving group 10 . The reduction is complete when the $\mathrm{N}$-alkylpicolinium radical $\mathbf{1 1}$ formed upon cleavage abstracts hydrogen from ascorbate or the ascorbate radical.

To introduce the NAP linker in self-immolative molecular beacons (iMB, Figure 1B), we used the bifunctional handle $\mathbf{1 3}$ in coupling reactions with two commercially available oligonucleotides

(Scheme S2). In this proof-of-concept study, the iMB was<smiles>NCCC[n+]1ccc(OCc2ccc(NC(=O)CC(=O)O)cc2)cc1</smiles>
designed for recognition of a 20-mer RNA segment transcribed from the b2a2 BCR-ABL fusion gene. A 5-mer stem (60\% GCcontent) was used to bring the ATTO425 dye into the vicinity of the quencher unit, which was comprised of three BMN535 dyes to allow efficient quenching of fluorescent emission. Fluorescence spectra of the iMB before and after hybridization with an RNA target confirmed that the iMB behaved like a "traditional" MB probe (Figure 2A and Figure S12). Despite the disruption of contiguous base pairing, introduced by the NAP linker, the hybridization with one equivalent RNA target induced an opening of the hairpin, as inferred from the 8-fold increase of fluorescence at $485 \mathrm{~nm}$.
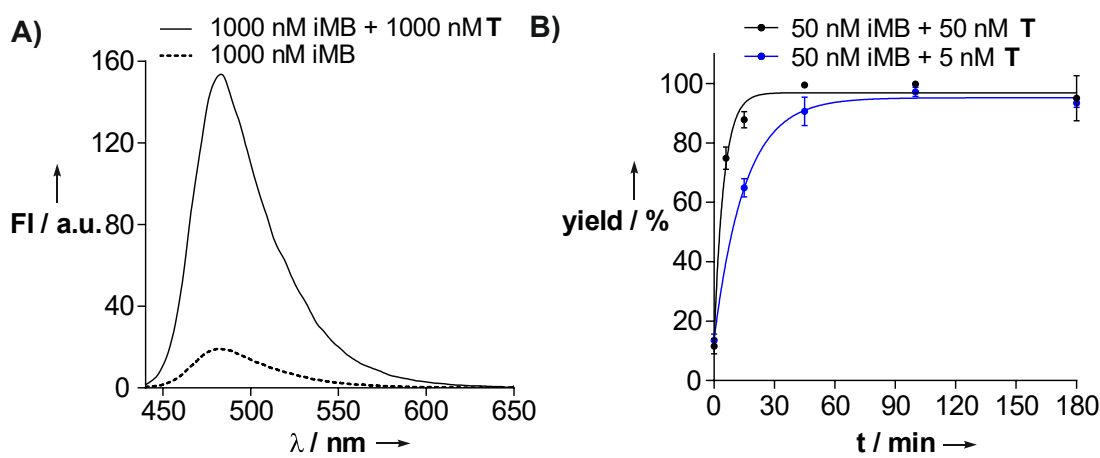

Figure 2. A) Fluorescence spectra of $\mathrm{iMB}$ in absence and presence of target (5'-CCAUCAAUAAGGAAGAAGCC-3'). B) Time course of templated photocleavage of iMB. Conditions: $10 \mathrm{mM} \mathrm{NaH} \mathrm{PO}_{4}, 100 \mathrm{mM} \mathrm{NaCl}, 2.5 \mathrm{mM} \mathrm{MgCl}, 5 \mathrm{mM} \mathrm{Asc}$., $\mathrm{pH}=$ $7.4, T=37^{\circ} \mathrm{C}$; for B): irradiation at $\lambda=455 \mathrm{~nm}$, yield determined by UPLC-FL (see figure S14A). 
Next, we examined the photo-induced self-immolation of the iMB by means of fluorescence detected UPLC analysis. In absence of target, no new product appeared after three hours irradiation time (Figure S14B). By contrast, the addition of one equivalent target to $50 \mathrm{nM}$ iMB triggered a rapid photo cleavage (Figure 2B, Figure S14A). Assuming pseudo-first order kinetics, we determined a reaction half-time $t_{1 / 2}=3.3 \mathrm{~min}$ (Figure $2 \mathrm{~B}$ ). Importantly, a surprisingly rapid cleavage was also obtained when the reaction was performed in presence of 0.1 equivalents template. After $45 \mathrm{~min}$, cleavage had occurred in $90 \%$ yield. This suggests that the products of the photo-induced cleavage reaction are readily displaced by excess $\mathrm{IMB}$ probe.

To probe the target affinity of the iMB photo cleavage products we performed UV melting experiments (Figure S17 and S18) with fragments 4a and 5a (Table 1), which contain the characteristic linker features (eg DBCO unit, alkyl spacers). The melting temperatures $\mathrm{T}_{\mathrm{M}}$ provided by the fragments, alone or in combination, were $10-20{ }^{\circ} \mathrm{C}$ lower than the $\mathrm{T}_{\mathrm{M}}=56^{\circ} \mathrm{C}$ of the intact iMBtarget duplex. We infer: self-immolation of the iMB does indeed lead to a loss of target affinity. Interestingly, a comparison of the $T_{M}$ values of the $\mathrm{iMB}$ in absence and presence of target suggested a surprisingly high stability of the iMB hairpin structure $\left(T_{M}(i M B)=57^{\circ} \mathrm{C}\right.$ vs. $\left.T_{M}(i M B \bullet T)=56^{\circ} \mathrm{C}\right)$. However, compared to the $\mathrm{iMB} \bullet T$ system the iMB melting curve (Figure S17) shows a rather shallow sigmoidal transition indicative of low cooperativity. This may facilitate hairpin opening.

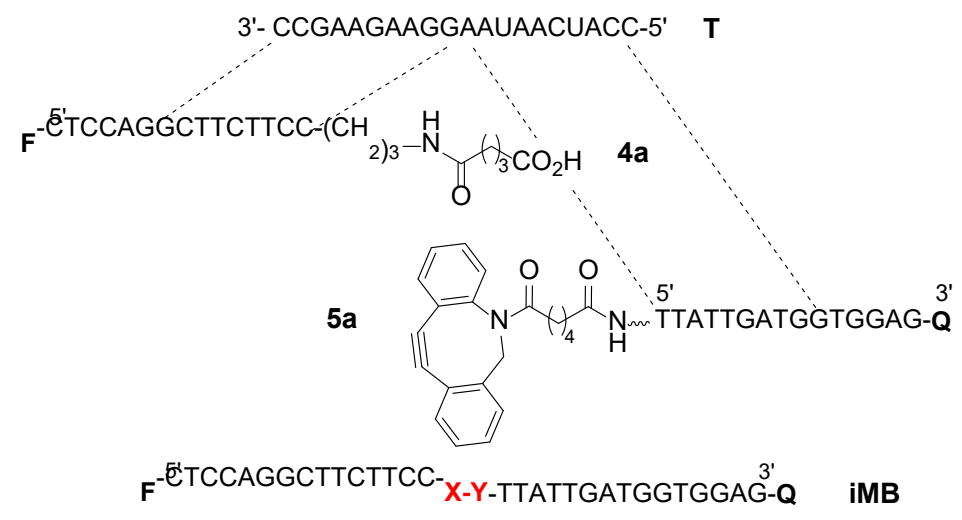

Table 1. Melting temperatures $T_{M}$ of complexes formed upon hybridization of target $T$ with the iMB and its fragments. ${ }^{[a]}$

\begin{tabular}{lllllll}
\hline Complex & $\mathrm{iMB}$ & $\mathrm{iMB} \cdot \mathbf{T}$ & $\mathbf{4 a} \mathbf{4} \mathbf{a} \cdot \mathbf{T}$ & $\mathbf{4 a} \cdot \mathbf{T}$ & $\mathbf{5 a} \cdot \mathbf{T}$ & $\mathbf{T}$ \\
\hline $\boldsymbol{T}_{\boldsymbol{M}} /{ }^{\circ} \mathbf{C}$ & 57 & 56 & 43 & 48 & 38 & 39 \\
\hline
\end{tabular}

[a] Conditions: $500 \mathrm{~nm}$ oligonucleotide, PBS-Buffer $\left(10 \mathrm{~mm} \mathrm{NaH}_{2} \mathrm{PO}_{4}, 100 \mathrm{~mm} \mathrm{NaCl}, 2.5 \mathrm{~mm} \mathrm{MgCl}, 5 \mathrm{~mm} \mathrm{Asc.,} \mathrm{pH}=7.4\right.$, detailed structures see Figure 3. F: ATTO425; Q: 3xBMN535. Melting curves see Figures S15 - S18.

Encouraged by the loss of target affinity upon photo-self-immolation, we analyzed fluorescence signalling after irradiation of the iMB in presence of substoichiometric target amounts. With $50 \mathrm{nM}$ $\mathrm{iMB}$, the presence of $5 \mathrm{nM}(0.1 \mathrm{eq})$ target was signalled by an $150 \%$ increase of fluorescence at 485 $\mathrm{nm}$ (Figure 3). Signalling was fast. A $100 \%$ signal increase was obtained after $15 \mathrm{~min}$. Without photoirradiation the non-cleaved $\mathrm{iMB}$ afforded a $52 \%$ signal increase, which corresponds to the signal expected for 'traditional' non-cleavable MB probe with similar fluorescence turn-on characteristics (Table 2). This signal increase afforded by the non-cleaved probe falls to $11 \%$ or $4 \%$ with 0.02 or 0.005 eq target, respectively. With $125 \%$ and $64 \%$ change of signal, much higher signalling was observed after 220 min irradiation. Of note, marked $30 \%$ signal increases were obtained already after 45 min or less (Figure 3 ). These experiments point to the advantage of self- 
immolating MB probes: a single target molecule can activate the fluorescence of many probe molecules.

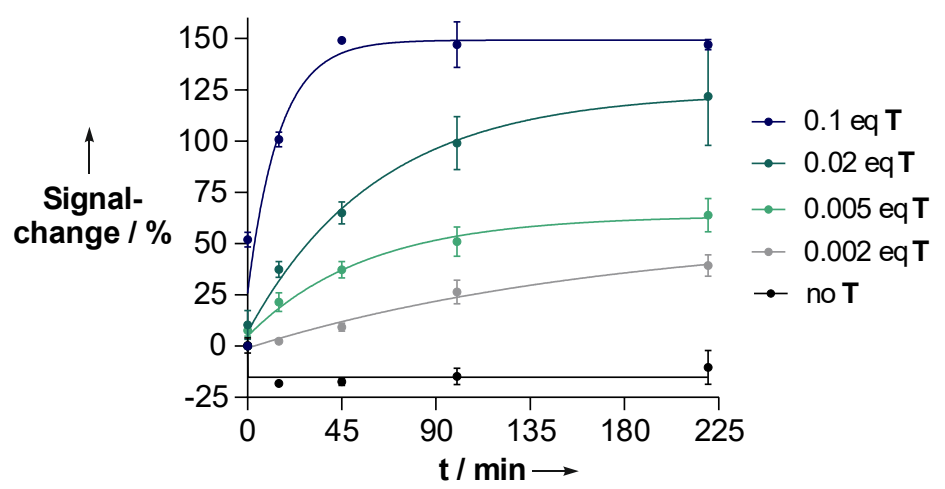

Figure 3. Time course of fluorescence signalling upon iMB photocleavage at substoichiometric target T. Conditions: $50 \mathrm{nM}$ iMB, $\mathrm{c}(\mathrm{T})$ as indicated in buffer $\left(10 \mathrm{~mm} \mathrm{NaH}_{2} \mathrm{PO}_{4}, 100 \mathrm{~mm} \mathrm{NaCl}, 2.5 \mathrm{~mm} \mathrm{MgCl}, 5 \mathrm{~mm} \mathrm{Asc}\right.$., $\left.\mathrm{pH}=7.4\right), \mathrm{T}=37^{\circ} \mathrm{C}$, irradiation at $455 \mathrm{~nm}$. Signal change $=\left(F / F_{0}-1\right) \times 100 \%, F, F_{0}$ is fluorescence intensity at $485 \mathrm{~nm}\left(\lambda_{\text {ex }}=430 \mathrm{~nm}\right)$ after or before addition of target.

Table 2. Signal enhancement prior to and after photoirradiation of iMB.

\begin{tabular}{lll}
\hline Equivalents T & $\begin{array}{l}\text { Signal change } \\
\text { cleavage / \% }\end{array}$ & $\begin{array}{l}\text { Signal change }{ }^{[a]} \text { after 220 } \\
\text { min photoirradiation / \% }\end{array}$ \\
\hline 0.1 & $52 \pm 3.5$ & $\mathbf{1 4 7} \pm \mathbf{2}$ \\
0.02 & $11 \pm 3.1$ & $\mathbf{1 2 4} \pm \mathbf{4 4}$ \\
0.01 & $7 \pm 1.4$ & $\mathbf{1 0 0 \pm 4 0}$ \\
0.005 & $4 \pm 2.3$ & $\mathbf{6 4} \pm \mathbf{8}$ \\
0.002 & Not detectable & $\mathbf{3 9 \pm 5}$ \\
\hline
\end{tabular}

[a] Signal change $[\%]=\left(F / F_{0}-1\right) \times 100 \%$. Conditions: see Fig. 3

The analysis of template-induced fluorescence signalling upon photo-cleavage shown in Figure 3 revealed that the maximum signal enhancement (see Figure 2A and Figure S12) was never reached. Control experiments showed that the ATTO425 coumarin dye suffers from photo bleaching (see Figure S13). Though bleaching reduces the achievable signal enhancement, it helps to reduce the background signal in absence of template.

Next, we investigated the limit of detection (LOD). After 100 min photoirradiation in PBS buffer, $100 \mathrm{pM}$ target provided a $27 \%$ signal enhancement (Figure 4A) that exceeded the standard error of the measurements by a factor of 3 ( $3 \sigma$ criterion). For further decreases of the LOD, Tween 20 was added to the buffer. This detergent presumably does not only hinder adsorption or unwanted aggregation but potentially serves also as an anti-fade agent. With this adjustment, 5 pM RNA target afforded a $52 \pm 8 \%$ signal increase after $100 \mathrm{~min}$ (compared to $23 \pm 4 \%$ without target, see Table S2-S3).

In subsequent experiments, we evaluated the sequence specificity of the iMB probe (Figure $4 \mathrm{~B}$ ). For this purpose, the iMB probe was incubated with a single mismatched RNA-target (1Mm), a target with two mismatched nucleotides $(\mathbf{2} \mathbf{M m})$ and a random target $(\mathbf{M r})$. In addition, a perfectly complementary DNA-target ( $\mathbf{M}_{\mathrm{DNA}}$ ) was added. After 100 min photoirradiation, the signal remained virtually unchanged when the $\mathrm{iMB}$ was incubated with the random sequence control or the target 
containing two mismatched nucleotides. Incubation with the single mismatched target resulted in a negligible signal change. As expected, the complementary DNA target promoted photo cleavage.
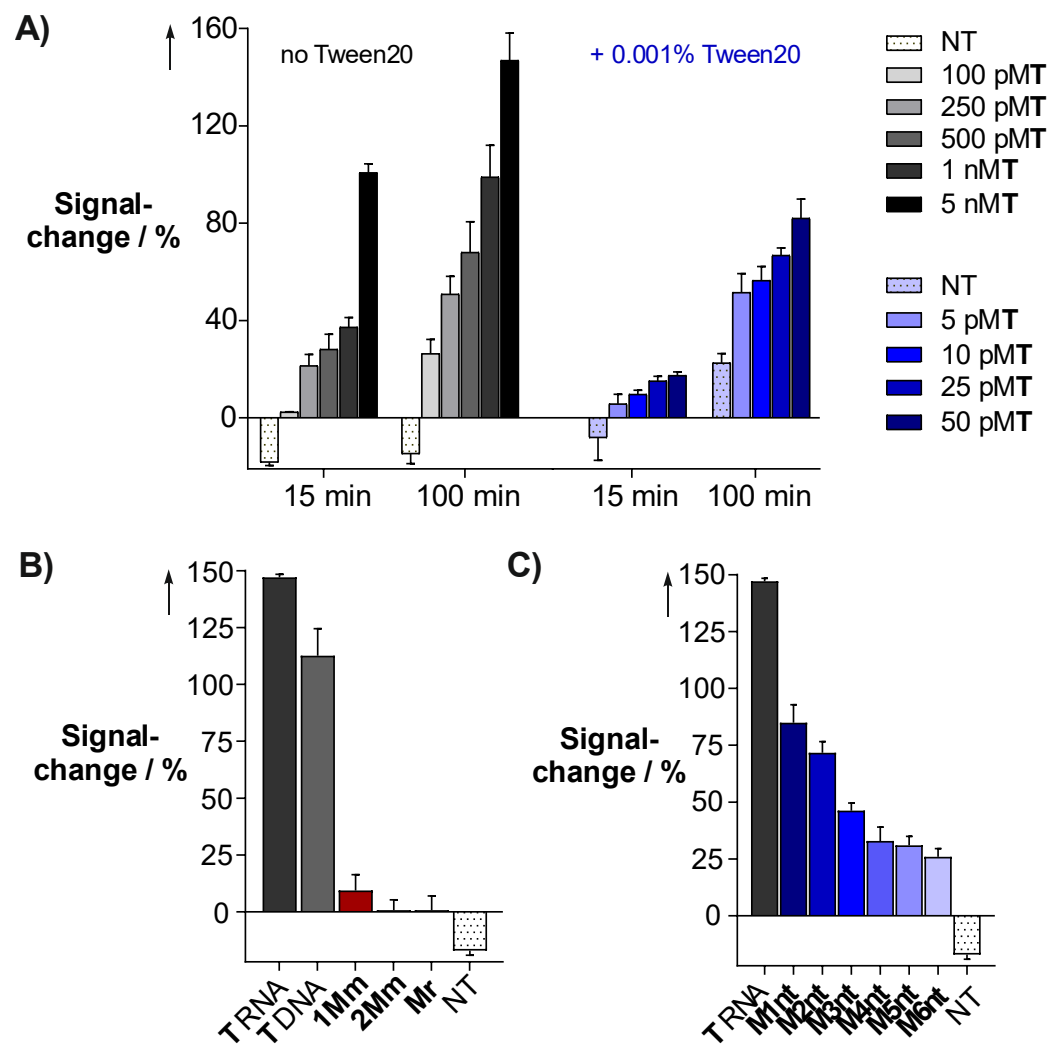

Figure 4. Fluorescence signal change from iMB after A) $15 \mathrm{~min} / 100 \mathrm{~min}$ photoirradiation in presence of 0.1-0.0001 eq target $\mathrm{T}$. Dependence of signalling from $\mathrm{iMB}$ on $\mathrm{B}$ ) target sequence and $\mathrm{C}$ ) number of gap nucleotides opposite the NAP linkage after 220 min. Conditions: $50 \mathrm{~nm} \mathrm{iMB,} 5 \mathrm{nM}$ (or lower when indicated) target, $10 \mathrm{~mm} \mathrm{NaH}_{2} \mathrm{PO}_{4}, 100 \mathrm{~mm} \mathrm{NaCl}, 2.5$ $\mathrm{mM} \mathrm{MgCl} 2,5 \mathrm{~mm}$ Asc., $0.001 \%$ Tween20 (if added), $\mathrm{pH}=7.4,37^{\circ} \mathrm{C}$, irradiation at $455 \mathrm{~nm}$. Signal change $=\left(\mathrm{F} / \mathrm{F}_{0}-1\right) \times 100 \%$.

In further control experiments, the targeted segments were separated by an increasing number of gap nucleotides (Figure 4C). Targets including one or two nucleotide insertions still provided for marked signal enhancements. Signaling gradually decreased as the distance between targeted segments was increased. Apparently, the cleavable linker within the iMB loop portion induces a certain degree of tolerance to nucleotide insertions between the targeted segments. We attribute this behavior to a bivalency effect. The spacer-separated oligonucleotide segments within the iMB loop resemble a spacer-linked bivalent receptor, which recognizes a bivalent ligand (that is the target). As previously reported, bivalent interactions loose strength as the distance between the receptor-ligand pairs increases. ${ }^{[11]}$ The highest affinity should be provided by a target that enables coaxial stacking of the iMB loop segments and indeed, the highest fluorescent signal was obtained with a "gapless" target. Despite the tolerance for nucleotide insertions, we wish to note that a target that involves two $10 \mathrm{nt}$ segments separated by less than 6 nucleotides should still be unique.

In conclusion, we have developed a photochemical method for signal amplified nucleic acid detection. In contrast to previously reported chemical methods, the self-immolative molecular beacon (iMB) approach is based on template-controlled cleavage leading to products that have lower template affinity than the probe before reaction. The iMB probe studied provided a $5 \mathrm{pM}$ limit for detection of an RNA target in buffer. First experiments in cell lysate and RNA extract (Figure S2O and S21) indicate the robustness of the method, though the limit of detection is affected in such complex 
matrices. Picomolar detection limits have also been reported for reaction systems that induced transfer or cleavage of fluorophores ${ }^{[5 f, 55,12]}$, or removal of fluorescence quencher groups (such as azide, tetrazine, vinyl ether or bromine substituents) from fluorophores. ${ }^{[5 a-c, 5 e, 13]}$ It is instructive to compare the results of our study with previous template-controlled photochemical reactions. Winssinger developed a reaction system involving two oligonucleotides and two PNA strands. Triggered by only $2 \mathrm{pM}$ template, a combination of hybridization chain reactions and $[\mathrm{Ru}]^{2+}$-mediated photocleavage of NAP-quenched PNA-fluorophore conjugates provided for a $4 \%$ signal change after a $30 \mathrm{~h}$ reaction time. ${ }^{[\mathrm{hh}]}$ The iMB probe required $100 \mathrm{~min}$ to signal $5 \mathrm{pM}$ target by means of $30 \%$ fluorescence increase relative to the no template reaction. Mokhir used DNA-photosensitizer conjugates for formation of singlet oxygen to induce the cleavage of 9-alkoxyanthracen-linked fluorophore-DNA conjugates. A 10 pM detection limit was reported for a 30 min reaction involving the concerted action of four dye-labeled oligonucleotide conjugates. ${ }^{[5 d]}$ Contrary to this set-up and all previously reported templated chemistries our method comprises the use of a single probe. Unimolecular hybridization probes such as molecular beacons have been widely applied.

With the current iMB system fluorescence-based nucleic acid detection is limited by a relatively modest fluorescence enhancement (8-fold) upon iMB opening, and photobleaching. Alternative photosensitizer schemes may allow for improvements. Based on data from Falvey et al., an exergonic photo-reductive cleavage of NAP linkers should be feasible when conditions of the Rehm-Weller equation

$\Delta G_{C T}=23.06\left(E_{O x}-E_{R e d}-E_{0.0}+0.06\right)<0$

are met $\left(E_{O x}=\right.$ oxidation potential of photosensitizer, $E_{R e d}=$ reduction potential of $N A P=-1.1 \mathrm{~V}, E_{0.0}=$ energy of sensitizer singlet state in eV). ${ }^{[6]}$ Some BODIPY dyes and the 6,8-difluoro-coumarin as well as other dyes such as carbopyronines should be applicable. ${ }^{[14]}$ In analogy to work published from Falvey and Winssinger, iMB probes may also involve a quenched $\left[\mathrm{Ru}(\mathrm{bpy})_{3}\right]^{2+}$ dye for photo-catalyzing the cleavage of NAP-caged coumarin linkers. ${ }^{[8 a, 10,14 d]}$

The data obtained in this study proves the feasibility of nucleic acid cleavage as a new category of DNA/RNA-templated reactions. We showed that a self-immolating option improves the sensitivity of DNA molecular beacons. The concept is probably not restricted to the photo-reductive cleavage of NAP-type linkers. Other photo-triggered cleavage reactions are known. With this and the alternative labeling schemes discussed above, we consider the iMB principle as a new reaction paradigm for DNA/RNA detection chemistries. It seems likely that further improvements allowing fluorescence detection of subpicomolar target are within reach.

\section{Experimental Section}

Experimental Details can be found in the supporting information.

\section{Acknowledgements}

This work was funded by the European Research Council's Horizon 2020 programme (ERC AdG, TRIGGDRUG). 


\section{Keywords}

oligonucleotides $\bullet$ fluorescent probes $\bullet$ Molecular Beacon $\bullet$ photo chemistry $\bullet$ RNA recognition

\section{References}

[1] a) S. Tyagi, F. R. Kramer, Nat. Biotechnol. 1996, 14, 303-308; b) J. Zheng, R. Yang, M. Shi, C. Wu, X. Fang, Y. Li, J. Li, W. Tan, Chem. Soc. Rev. 2015, 44, 3036-3055.

[2] a) D. M. Kolpashchikov, Chem. Rev. 2010, 110, 4709-4723; b) A. A. Martí, S. Jockusch, N. Stevens, J. Ju, N. J. Turro, Acc. Chem. Res. 2007, 40, 402-409; c) A. Okamoto, Chem. Soc. Rev. 2011, 40, 5815-5828; d) F. Hövelmann, O. Seitz, Acc. Chem. Res. 2016, 49, 714-723.

[3] a) P. Zhang, T. Beck, W. Tan, Angew. Chem. Int. Ed. Engl. 2001, 40, 402-405. Angew. Chem., 2000, 113, 416-419; b) J. J. Li, X. Fang, S. M. Schuster, W. Tan, Angew. Chem. Int. Ed. Engl. 2000, 39, 1049-1052. Angew. Chem., 2000, 112, 1091-1094; c) C. J. Yang, H. Lin, W. Tan, J. Am. Chem. Soc. 2005, 127, 12772-12773; d) T. N. Grossmann, L. Röglin, O. Seitz, Angew. Chem. Int. Ed. Engl. 2007, 46, 5223-5225. Angew. Chem., 2007, 119, 5315-5318; e) Y. Hara, T. Fujii, H. Kashida, K. Sekiguchi, X. Liang, K. Niwa, T. Takase, Y. Yoshida, H. Asanuma, Angew. Chem. Int. Ed. Engl. 2010, 49, 5502-5506. Angew. Chem., 2010, 122, 5634-5638; f) C. Holzhauser, H.-A. Wagenknecht, Angew. Chem. Int. Ed. Engl. 2011, 50, 7268-7272. Angew. Chem. 2011, 123, 7406-7410; g) E. Socher, L. Bethge, A. Knoll, N. Jungnick, A. Herrmann, O. Seitz, Angew. Chem. Int. Ed. Engl. 2008, 47, 9555-9559. Angew. Chem. 2008, 120, 49, 96979701.

[4] a) K. Gorska, N. Winssinger, Angew. Chem. Int. Ed. Engl. 2013, 52, 6820-6843. Angew. Chem., 2013, 125, 6956-6980; b) A. P. Silverman, E. T. Kool, Chem. Rev. 2006, 106, 3775-3789; c) T. N. Grossmann, A. Strohbach, O. Seitz, Chembiochem 2008, 9, 2185-2192.

[5] a) A. Shibata, T. Uzawa, Y. Nakashima, M. Ito, Y. Nakano, S. Shuto, Y. Ito, H. Abe, J. Am. Chem. Soc. 2013, 135, 14172-14178; b) D. K. Prusty, A. Herrmann, J. Am. Chem. Soc. 2010, 132, 12197-12199; c) H. Wu, B. T. Cisneros, C. M. Cole, N. K. Devaraj, J. Am. Chem. Soc. 2014, 136, 17942-17945; d) O. Zozulia, T. Bachmann, A. Mokhir, Bioconjug. Chem. 2019, 30, 2023-2031; e) D. K. Prusty, M. Kwak, J. Wildeman, A. Herrmann, Angew. Chem. Int. Ed. Engl. 2012, 51, 11894-11898. Angew. Chem. 2012, 124, 12604-12608; f) O. Zavoiura, U. Resch-Genger, O. Seitz, Bioconjug. Chem. 2018, 29, 1690-1702; g) T. N. Grossmann, O. Seitz, J. Am. Chem. Soc. 2006, 128, 15596-15597; h) K. T. Kim, S. Angerani, D. Chang, N. Winssinger, J. Am. Chem. Soc. 2019, 141, 16288-16295.

[6] a) C. Sundararajan, D. E. Falvey, J. Org. Chem. 2004, 69, 5547-5554; b) C. Sundararajan, D. E. Falvey, Org. Lett. 2005, 7, 2631-2634; c) C. Sundararajan, D. E. Falvey, Photochem. Photobiol. Sci. 2006, 5, 116-121.

[7] J. B. Borak, D. E. Falvey, J. Org. Chem. 2009, 74, 3894-3899.

[8] a) D. Chang, E. Lindberg, N. Winssinger, J. Am. Chem. Soc. 2017, 139, 1444-1447; b) D. Chang, K. T. Kim, E. Lindberg, N. Winssinger, Bioconjug. Chem. 2018, 29, 158-163.

[9] C. Sundararajan, D. E. Falvey, J. Am. Chem. Soc. 2005, 127, 8000-8001.

[10] J. B. Edson, L. P. Spencer, J. M. Boncella, Org. Lett. 2011, 13, 6156-6159. 
[11] N. Dubel, S. Liese, F. Scherz, O. Seitz, Angew. Chem. Int. Ed. Engl. 2019, 58, 907-911. Angew. Chem. 2019, 131, 918-923.

[12] T. N. Grossmann, L. Röglin, O. Seitz, Angew. Chem. Int. Ed. Engl. 2008, 47, 7119-7122. Angew. Chem. 2008, 120, 7228-7231.

[13] a) H. Wu, S. C. Alexander, S. Jin, N. K. Devaraj, J. Am. Chem. Soc. 2016, 138, 11429-11432; b) W. A. Velema, E. T. Kool, J. Am. Chem. Soc. 2017, 139, 5405-5411.

[14] a) D. E. Falvey, C. Sundararajan, Photochem. Photobiol. Sci. 2004, 3, 831-838; b) J. B. Borak, D. E. Falvey, Photochem. Photobiol. Sci. 2010, 9, 854-860; c) J. B. Borak, S. López-Sola, D. E. Falvey, Org. Lett. 2008, 10, 457-460; d) J. B. Borak, D. E. Falvey, J. Org. Chem. 2009, 74, 38943899. 
A self-immolative molecular beacon for amplified nucleic acid detection

Magdalena Roth and Oliver Seitz* 


\section{Materials and Methods}

\subsection{Materials}

Modified oligonucleotides (S9 and S11) were purchased from Biomers (Ulm, Germany). Chemicals for the purification of DNA such as acetonitrile (Water content $<30 \mathrm{ppm}$ ), isopropanol and ethanol were purchased from Roth (Karlsruhe, Germany). All other chemicals were purchased from Acros, Sigma Aldrich, Fluka, TCl or abcr and were used without further purification. Water was purified with an Astacus Milli-Q Ultra Pure Water Purification System from membraPure GmbH (Bodenheim, Germany).

\subsection{Instruments and Methods}

Semipreparative HPLC of oligonucleotides was performed on a 1105 HPLC System from Gilson equipped with an UV/Vis-detector (260 nm detection wavelength) and a Waters X-Bridge BEH $130 \mathrm{C} 18(10 \times 150 \mathrm{~mm}), 5 \mu \mathrm{m}$ column at $55^{\circ} \mathrm{C}$. The flow rate was set to $7 \mathrm{~mL} / \mathrm{min}$. A binary mixture of $\mathrm{A}(0.1 \mathrm{M}$ triethylammoniumacetate at $\mathrm{pH}=7.3)$ and $\mathrm{B}$ (acetonitrile) was used as mobile phase.

Analytical HPLC was performed on a 1105 HPLC System from Gilson equipped with an UV/Vis-detector (260 nm detection wavelength) and a Waters X-Bridge BEH $130 \mathrm{C} 18(4.6 \times 250 \mathrm{~mm}), 5 \mu \mathrm{m}$ column at $55^{\circ} \mathrm{C}$. The flow rate was set to $1.5 \mathrm{~mL} / \mathrm{min}$. A binary mixture of $\mathrm{A}(0.1 \mathrm{M}$ triethylammoniumacetate at $\mathrm{pH}=7.3)$ and $\mathrm{B}$ (acetonitrile) was used as mobile phase.

MALDI-TOF mass spectrometry was performed on a Shimadzu Axima Confidence (positive linear mode). As an excitation source, a nitrogen Laser was used at $\lambda=337 \mathrm{~nm}$. HPA $(0.15 \mathrm{M}$ 2,3,4-trihydroxyacetophenone in MeCN/Water $(1: 1$ [v/v] with $0.5 \mathrm{M}$ diammonium-citrate) was used as a Matrix.

Fluorescence measurements were performed on a Cary Varian Eclipse (Agilent technologies) spectrometer equipped with a peltier block by using either suprasil ultra micro quartz cuvettes $(100 \mu \mathrm{L}, \mathrm{d}=1 \mathrm{~cm})$ or suprasil quartz cuvettes $(1 \mathrm{~mL}, \mathrm{~d}=1 \mathrm{~cm})$ at either $25{ }^{\circ} \mathrm{C}$ or $37^{\circ} \mathrm{C}$. All measurements were performed in degassed phosphate buffer $\left(10 \mathrm{mM} \mathrm{NaH}_{2} \mathrm{PO}_{4}, 100 \mathrm{mM} \mathrm{NaCl}, \mathrm{pH}=\right.$ 7.4) containing $\mathrm{MgCl}_{2}$, sodium ascorbate and Tween20 as indicated (ex: $430 \mathrm{~nm}$, slit: $5 \mathrm{~nm}$, em: $485 \mathrm{~nm}$, slit: $5 \mathrm{~nm}$ ). All measurements were done in triplicate.

For UPLC analysis a Waters ACQUITY was equipped with an ACQUITY UPLC TUV detector as well as a fluorescence detector (ex: $430 \mathrm{~nm}$, em: $490 \mathrm{~nm}$ ). An AQCUITY UPLC BEH oligonucleotide C18 (130 A, $1.7 \mu \mathrm{m}, 2.1 \cdot 50 \mathrm{~mm})$ column was used at a flow rate of $0.5 \mathrm{~mL} / \mathrm{min}$ at $50{ }^{\circ} \mathrm{C}$. As a mobile phase, a binary mixture of $\mathrm{A}(0.1 \mathrm{M}$ triethylammoniumacetate at $\mathrm{pH}=7.3)$ and $\mathrm{B}$ (acetonitrile) was used.

Photo-induced cleavage was performed in F-96 well plates from PerkinElmer sealed with Greiner EASYseal clear A5596 - 100 EA (Sigma-Aldrich) seal-film. The well plate was irradiated with a collimated LED-light placed approx. $15 \mathrm{~cm}$ above the plate (455 nm, $1 \mathrm{~W}$ : Thorlabs, part. Number M455L2-C2 - www.thorlabs.com) using 75\%-85\% brightness for set times. The well-plate was cooled/heated with the aid of a custom-made-aluminum-block equipped with a Julabo F250 temperature controller (JULABO $\mathrm{GmbH}$ )

UV melting curves were measured at $260 \mathrm{~nm}$ using a JASCO spectrometer equipped with a peltier block in UV quartz cuvettes $(\mathrm{d}=1 \mathrm{~cm}), V=1 \mathrm{~mL}, \mathrm{c}=500 \mathrm{nM}$. The oligonucleotides were mixed in a 1:1 ratio. The melting curves were recorded at a rate of $0.5^{\circ} \mathrm{C} / \min \left(20^{\circ} \mathrm{C}-90^{\circ} \mathrm{C}\right)$. This was repeated $4 x$ per melting curve. The absorption was normalized and the melting temperature was calculated from the first derivative.

Cell lysate: To release the adherent HEK293WT cells from the surface of the culture dish, the medium was removed and washed once with PBS. Subsequently $0.25 \%$ trypsin EDTA (ThermoFischer) was added and incubated for $3-5$ min at $37^{\circ} \mathrm{C}$. The cells were detached from the culture dish and the trypsin reaction was stopped by adding full medium (DMEM, 10\% FBS (serum), 1x streptomycin/penicillin). The suspension was centrifuged $(200 \times \mathrm{g}, 5 \mathrm{~min})$. The supernatant was discarded. Next, the cells were resuspended in medium and counted (ThermoFischer Countess). The desired number of cells were centrifuged and washed with PBS buffer. The cells were then redissolved in TRIS buffer and proteinase $\mathrm{K}\left(3-4 \mathrm{~h}, 50^{\circ} \mathrm{C}, 250 \mu \mathrm{g} / \mathrm{mL}\right.$ final conc.) was added. After centrifugation (( $200 \times \mathrm{g}, 5 \mathrm{~min}, \mathrm{RT})$, the desired lysate was filtrated before use.

RNA-extract: a cell pellet from 437 mio. HEK293WT cells was dissolved in $15 \mathrm{~mL}$ trizol (cooled). Cells were subsequently lysed by pipetting up and down until completely dissolved. Next, $3 \mathrm{~mL}$ chloroform was added and the mixture was agitated for 15 sec. The mix was incubated for $3 \mathrm{~min}$ at room temperature followed by centrifugation for $15 \mathrm{~min}$ at $13.000 \mathrm{rpm}\left(4^{\circ} \mathrm{C}\right)$. The upper layer containing the extracted RNA was carefully pipetted into a sterile falcon tube. One volume-part (pipetted volume of extracted RNA) of cold $\mathrm{iPrOH}$ was added along with $1 / 10-\mathrm{Volume}$ parts of $3 \mathrm{M}$ Na-Acetate. After precipitation overnight, the falcon was centrifuged at $4{ }^{\circ} \mathrm{C}$ for $15 \mathrm{~min}$ at $4000 \mathrm{rpm}$. The $\mathrm{iPrOH}$ was decanted and the precipitate was washed $10 \mathrm{x}$ with cooled $70 \% \mathrm{EtOH}-$ solution. The pellet was dried over argon and then resuspended in DEPC-Water. The concentration as well as the purity were determined via Nanodrop: Determined ratios (absorbance maxima):260/280: 1.98; 260/230: 2.3 
NMR spectra were recorded on a BRUKER Avance II (400 MHz) using $\mathrm{CDCl}_{3}, \mathrm{CD}_{3} \mathrm{OD}$ or DMSO-d6 as solvent, and were referenced with respective residual ${ }^{1} \mathrm{H}$-solvent peaks of $\mathrm{CHCl}_{3}(\delta=7.26 \mathrm{ppm}), \mathrm{CHD}_{2} \mathrm{OD}(\delta=3.31 \mathrm{ppm})$, and DMSO $(\delta=2.50$ $\mathrm{ppm})$ and ${ }^{13} \mathrm{C}$-solvent peaks of $\mathrm{CDCl}_{3}(\delta=77.0 \mathrm{ppm}), \mathrm{CD}_{3} \mathrm{OD}(\delta=49.05 \mathrm{ppm})$, and DMSO-d6 $(\delta=39.43 \mathrm{ppm})$.

LC-MS spectra were recorded using a Waters ACQUITY UPLC coupled with a QDa Mass Spectrometer System (electrospray ionization (ESI)) operating in positive mode on a Waters Acquity UPLC BEH C18 1-7 $\mu \mathrm{m}$ column.

\section{Synthesis and Characterization}

2.1 Synthesis of the N-Alkyl-picolinium cleavage linker (NAP-CL)

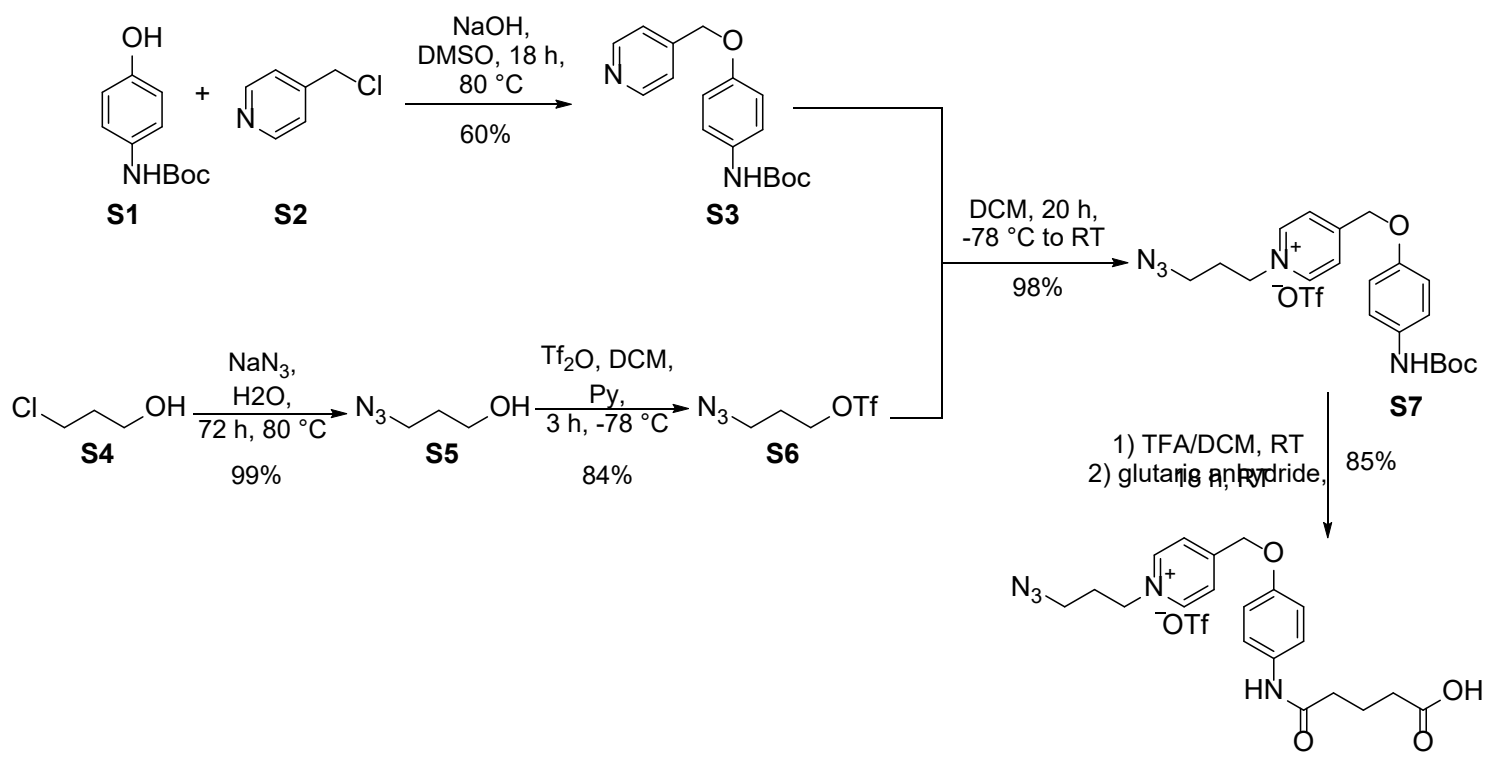

13

Scheme S1. Synthesis of the NAP linker 13

\subsubsection{4-tert.-Butyloxycarbonylamidophenyl-picolyl ether (S3)}

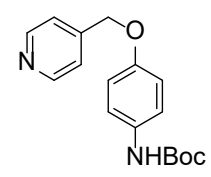

S3

In a two-neck flask under Ar, 4-N-Boc-aminophenol (S1) $(5.97 \mathrm{~g}, 28.0 \mathrm{mmol}, 1.0 \mathrm{eq})$ was dissolved in $60 \mathrm{~mL}$ dry DMSO. After heating to $50{ }^{\circ} \mathrm{C}, \mathrm{NaOH}(2.80 \mathrm{~g}, 70 \mathrm{mmol}, 2.5 \mathrm{eq})$ was added. The suspension was stirred at this temperature for $1 \mathrm{~h}$. Next, $3-$ chloro-methylpyridine (S2) $(4.64 \mathrm{~g}, 28.0 \mathrm{mmol}, 1.0 \mathrm{eq})$ was added within $2 \mathrm{~h}$. The reaction mixture was heated to $80^{\circ} \mathrm{C}$ and stirred for $18 \mathrm{~h}$. After cooling to room temperature, the mixture was poured onto $500 \mathrm{~mL}$ of ice and extracted from EtOAc (10 x $300 \mathrm{~mL})$. The combined organic layers were washed with water $(10 \times 300 \mathrm{~mL})$ and dried over $\mathrm{MgSO}_{4}$. The solvent was removed in vacuo and the crude product was purified via flash-chromatography (DCM/EtOAc $4: 1)$ to yield $\mathbf{S 3}(4.93 \mathrm{~g}, 60 \%)$ as a white solid. ${ }^{1} \mathrm{H}$ $\operatorname{NMR}\left(500 \mathrm{MHz}, \mathrm{CDCl}_{3}\right): \delta[\mathrm{ppm}]=8.60(\mathrm{dd}, J=4.5,1.5 \mathrm{~Hz}, 2 \mathrm{H}), 7.35(\mathrm{~d}, J=6.1 \mathrm{~Hz}, 2 \mathrm{H}), 7.28(\mathrm{~d}, J=8.3 \mathrm{~Hz}, 2 \mathrm{H}), 6.89-6.87(\mathrm{~m}$, 2H), $6.51(\mathrm{~s}, 1 \mathrm{H}), 5.05(\mathrm{~s}, 2 \mathrm{H}), 1.50(\mathrm{~s}, 9 \mathrm{H}) .{ }^{13} \mathrm{C}-\mathrm{NMR}\left(126 \mathrm{MHz}, \mathrm{CDCl}_{3}\right)$ : $\delta[\mathrm{ppm}]=154.2,153.2,149.9,146.6,132.4,121.1,120.6$, 115.3, 68.6, 28.5. LC-MS (ESI) RT = $2.4 \mathrm{~min}(3-80 \% \mathrm{~B}$ in $4 \mathrm{~min}) . \mathrm{m} / \mathrm{z}$ calcd for $\mathrm{C}_{17} \mathrm{H}_{20} \mathrm{~N}_{2} \mathrm{O}_{3}+\mathrm{H}^{+}: 301.15$ [M+H] $]^{+}$, found: 301.28 $[\mathrm{M}+\mathrm{H}]^{+}$.

\section{3-Azido-1-propanol (S5) ${ }^{[1]}$}

$\mathrm{N}_{3} \frown \mathrm{OH}$

S5

In a $100 \mathrm{~mL}$ flask, 3-Chloro-1-propanol (S4) $(1.89 \mathrm{~g}, 20.0 \mathrm{mmol}, 1.0 \mathrm{eq})$ was dissolved in $40 \mathrm{~mL}$ ddH $\mathrm{H}_{2} \mathrm{O}$. Sodium azide (2.60 g, $40.0 \mathrm{mmol}, 2.0 \mathrm{eq}$ ) was added successively. The reaction mixture was heated to $80^{\circ} \mathrm{C}$ and stirred for $72 \mathrm{~h}$. After cooling to RT, the crude mixture was extracted with DCM $(4 \times 70 \mathrm{~mL})$. The combined organic layers were dried over $\mathrm{MgSO}_{4}$. The solvent was 
removed in vacuo $\left(35^{\circ} \mathrm{C}\right.$, max. $\left.150 \mathrm{mbar}\right)$ to yield the product $(\mathbf{S 5}, 2.02 \mathrm{~g}, 99 \%)$ without further purification as a clear colorless oil. The NMR-data is in agreement with the given literature-data ${ }^{[1]}$. ${ }^{1} \mathrm{H}-\mathrm{NMR}\left(500 \mathrm{MHz}, \mathrm{CDCl}_{3}\right): \delta[p p m]=3.73(\mathrm{t}, \mathrm{J}=6.0 \mathrm{~Hz}, 2 \mathrm{H})$, $3.44(\mathrm{t}, J=6.6 \mathrm{~Hz}, 2 \mathrm{H}), 1.98(\mathrm{~s}, 1 \mathrm{H}), 1.91-1.72(\mathrm{~m}, 2 \mathrm{H}) .{ }^{13} \mathrm{C}-\mathrm{NMR}\left(126 \mathrm{MHz}, \mathrm{CDCl}_{3}\right): \delta[\mathrm{ppm}]=60.0,48.5,31.2$.

\subsubsection{3-Azido-1-triflyl-propanol (S6) ${ }^{[2]}$}

$\mathrm{N}_{3} \frown \mathrm{OTf}$

s6

In a $100 \mathrm{~mL}$ flask under Ar, 3-Azido-1-propanol (S5) $(2.00 \mathrm{~g}, 20.0 \mathrm{mmol}, 1.0 \mathrm{eq})$ was dissolved in $45 \mathrm{~mL}$ DCM and cooled to $0{ }^{\circ} \mathrm{C}$. At this temperature, pyridine $(2.62 \mathrm{~g}, 24.0 \mathrm{mmol}, 1.2 \mathrm{eq})$ was added and subsequently cooled to $-78^{\circ} \mathrm{C}$. Next, Triflic-anhydride $(6.23 \mathrm{~g}, 22.0 \mathrm{mmol}, 1.1 \mathrm{eq})$ was added within $20 \mathrm{~min}$. The reaction mixture was stirred for another $3 \mathrm{~h}$ at $-78^{\circ} \mathrm{C}$ and then warmed to RT. $30 \mathrm{~mL}$ sat. $\mathrm{NH}_{4} \mathrm{Cl}$ was added to quench the reaction followed by an extraction with EtOAc $(3 \times 70 \mathrm{~mL})$. The combined organic layers were dried over $\mathrm{MgSO}_{4}$. The solvent was removed in vacuo and the crude was purified with flash-chromatography (Hexane/EtOAc 10:1) to yield the product (S6, $3.91 \mathrm{~g}, 84 \%)$ as a clear colorless oil. The NMR-Data is in agreement with the given literature-data ${ }^{[2]}$. ${ }^{1} \mathrm{H}-\mathrm{NMR}\left(500 \mathrm{MHz}, \mathrm{CDCl}_{3}\right): \delta[\mathrm{ppm}]=4.63(\mathrm{t}, \mathrm{J}=6.0 \mathrm{~Hz}, 2 \mathrm{H}), 3.52(\mathrm{t}, \mathrm{J}=6.4 \mathrm{~Hz}, 2 \mathrm{H}), 2.08-2.06(\mathrm{~m}, 2 \mathrm{H}) .{ }^{13} \mathrm{C}-$ NMR $\left(126 \mathrm{MHz}, \mathrm{CDCl}_{3}\right): \delta[\mathrm{ppm}]=73.9,46.9,28.9$.

2.1.3 4-tert.-Butyloxycarbonylamidophenyl $\mathrm{N}$-azidopropylpicolinium ether (S7)<smiles>NCCC[n+]1ccc(COc2ccc(N=[Se])cc2)cc1</smiles>

In a $250 \mathrm{~mL}$ two-neck flask under Ar, S3 $(600 \mathrm{mg}, 2.0 \mathrm{mmol}, 1.0 \mathrm{eq})$ was dissolved in $170 \mathrm{~mL}$ dry DCM. The solution was cooled to $-78{ }^{\circ} \mathrm{C}$ and 3-azido-1-triflyl-propanol (S6) $(653 \mathrm{mg}, 2.80 \mathrm{mmol}, 1.4 \mathrm{eq})$ was added successively. The reaction mixture was warmed to RT and stirred for another $20 \mathrm{~h}$. The solvent was removed in vacuo and the crude product was purified via flashchromatography (DCM/MeOH 10:1) to yield $\mathbf{S} 7(1.05 \mathrm{~g}, 99 \%)$ as a white solid. ${ }^{1} \mathrm{H}-\mathrm{NMR}\left(500 \mathrm{MHz}, \mathrm{CD}_{3} \mathrm{OD}\right): \delta[\mathrm{ppm}]=8.97(\mathrm{~d}, \mathrm{~J}$ $=6.8 \mathrm{~Hz}, 2 \mathrm{H}), 8.19(\mathrm{~d}, J=6.7 \mathrm{~Hz}, 2 \mathrm{H}), 7.37(\mathrm{~d}, J=8.9 \mathrm{~Hz}, 2 \mathrm{H}), 7.11-6.76(\mathrm{~m}, 2 \mathrm{H}), 5.45(\mathrm{~s}, 2 \mathrm{H}), 4.73(\mathrm{t}, J=7.2 \mathrm{~Hz}, 2 \mathrm{H}), 3.55$ (s, 2H), 3.37 (s, 2H), $2.43-2.14(\mathrm{~m}, 2 \mathrm{H}), 1.53(\mathrm{~s}, 9 \mathrm{H}) .{ }^{13} \mathrm{C}-\mathrm{NMR}\left(126 \mathrm{MHz}, \mathrm{CD}_{3} \mathrm{OD}\right): \delta[\mathrm{ppm}]=160.4,155.6,154.5,145.9,134.9$, $126.5,123.1,121.8,120.5,116.2,80.8,68.6,60.11,31.2,28.7$. LC-MS (ESI) RT $=2.7 \mathrm{~min}(3-80 \% \mathrm{~B}$ in $4 \mathrm{~min})$. $\mathrm{m} / \mathrm{z} \mathrm{calcd}$ for $\mathrm{C}_{21} \mathrm{~F}_{3} \mathrm{H}_{26} \mathrm{~N}_{5} \mathrm{O}_{6} \mathrm{~S}: 533.15$, found: 384.24 [M-OTf] ${ }^{+}$.

2.1.4 NAP-CL (13)<smiles>N#CCC[n+]1ccc(COc2ccc(NC(=O)CCCC(=O)O)cc2)cc1</smiles>

To a $50 \mathrm{~mL}$ flask under Ar, S7 (1.05 g, $1.98 \mathrm{mmol}, 1.0 \mathrm{eq})$ was added and dissolved in DCM/TFA (1:1, [v/v] $16 \mathrm{~mL})$ and stirred for $1 \mathrm{~h}$ at RT. The deprotection was followed via LC-MS. After quantitative deprotection, the solvent mixture was evaporated by means of an argon stream, washed $5 \mathrm{x}$ with DCM and dried under reduced pressure for $30 \mathrm{~min}$. The residue was dissolved in water $(10 \mathrm{~mL})$ and sat. $\mathrm{NaHCO}_{3}$ was added until the solution reached $\mathrm{pH}=8.0$ and a white solid precipitated. The precipitate was dissolved in EtOAc followed by an extraction with EtOAc $(5 \times 60 \mathrm{~mL})$. The combined organic layers were dried over $\mathrm{MgSO}_{4}$ and the solvent was reduced in vacuo. The aniline derivative was used without further purification.

To a $250 \mathrm{~mL}$ flask under Ar, aniline intermediate $(745 \mathrm{mg}, 1.72 \mathrm{mmol}, 1.0 \mathrm{eq})$ was added and dissolved in dry EtOAc (90 mL). Next, glutaric anhydride $(255 \mathrm{mg}, 2.24 \mathrm{mmol}, 1.3 \mathrm{eq})$ was added. The reaction mixture was heated to $50{ }^{\circ} \mathrm{C}$ until the suspension was completely dissolved. The solution was then stirred at RT for $18 \mathrm{~h}$. The formed precipitate was filtrated, washed with cold EtOAc and subsequently dried at reduced pressure. The product $(\mathbf{1 3}, 800 \mathrm{mg}, \mathbf{8 5} \%)$ was obtained as a pale-yellow solid and used without further purification. ${ }^{1} \mathrm{H}-\mathrm{NMR}\left(500 \mathrm{MHz}, \mathrm{CD}_{3} \mathrm{OD}\right)$ : $\delta[\mathrm{ppm}]=8.96(\mathrm{~d}, J=6.8 \mathrm{~Hz}, 2 \mathrm{H}), 8.17(\mathrm{~d}, J=6.6 \mathrm{~Hz}, 2 \mathrm{H}), 7.59-7.39$ $(\mathrm{m}, 2 \mathrm{H}), 7.09-6.92(\mathrm{~m}, 2 \mathrm{H}), 5.45(\mathrm{~s}, 2 \mathrm{H}), 4.71(\mathrm{t}, J=7.2 \mathrm{~Hz}, 2 \mathrm{H}), 3.51(\mathrm{t}, J=6.3 \mathrm{~Hz}, 2 \mathrm{H}), 2.40(\mathrm{dt}, J=12.7,7.3 \mathrm{~Hz}, 4 \mathrm{H}), 2.33-$ $2.17(\mathrm{~s}, 2 \mathrm{H}), 1.98(\mathrm{dd}, J=16.0,8.6 \mathrm{~Hz}, 3 \mathrm{H}), 1.24(\mathrm{t}, J=7.1 \mathrm{~Hz}, 1 \mathrm{H}) .{ }^{13} \mathrm{C}-\mathrm{NMR}\left(126 \mathrm{MHz}, \mathrm{CD}_{3} \mathrm{OD}\right): \delta[\mathrm{ppm}]=179.9,173.6,160.2$, $155.5,145.9,134.3,126.5,123.2,116.1,68.6,60.1,36.8,34.2,31.2,22.2,20.9$. LC-MS (ESI) RT = $1.8 \mathrm{~min}(3-80 \% \mathrm{~B}$ in $4 \mathrm{~min})$. $\mathrm{m} / \mathrm{z}$ calcd for $\mathrm{C}_{21} \mathrm{~F}_{3} \mathrm{H}_{24} \mathrm{~N}_{5} \mathrm{O}_{7} \mathrm{~S}: 547.13 \mathrm{~g} / \mathrm{mol}$, found: 398.38 [M-OTf] ${ }^{+}$. 


\section{$2.2 \quad$ NMR-Spectra}

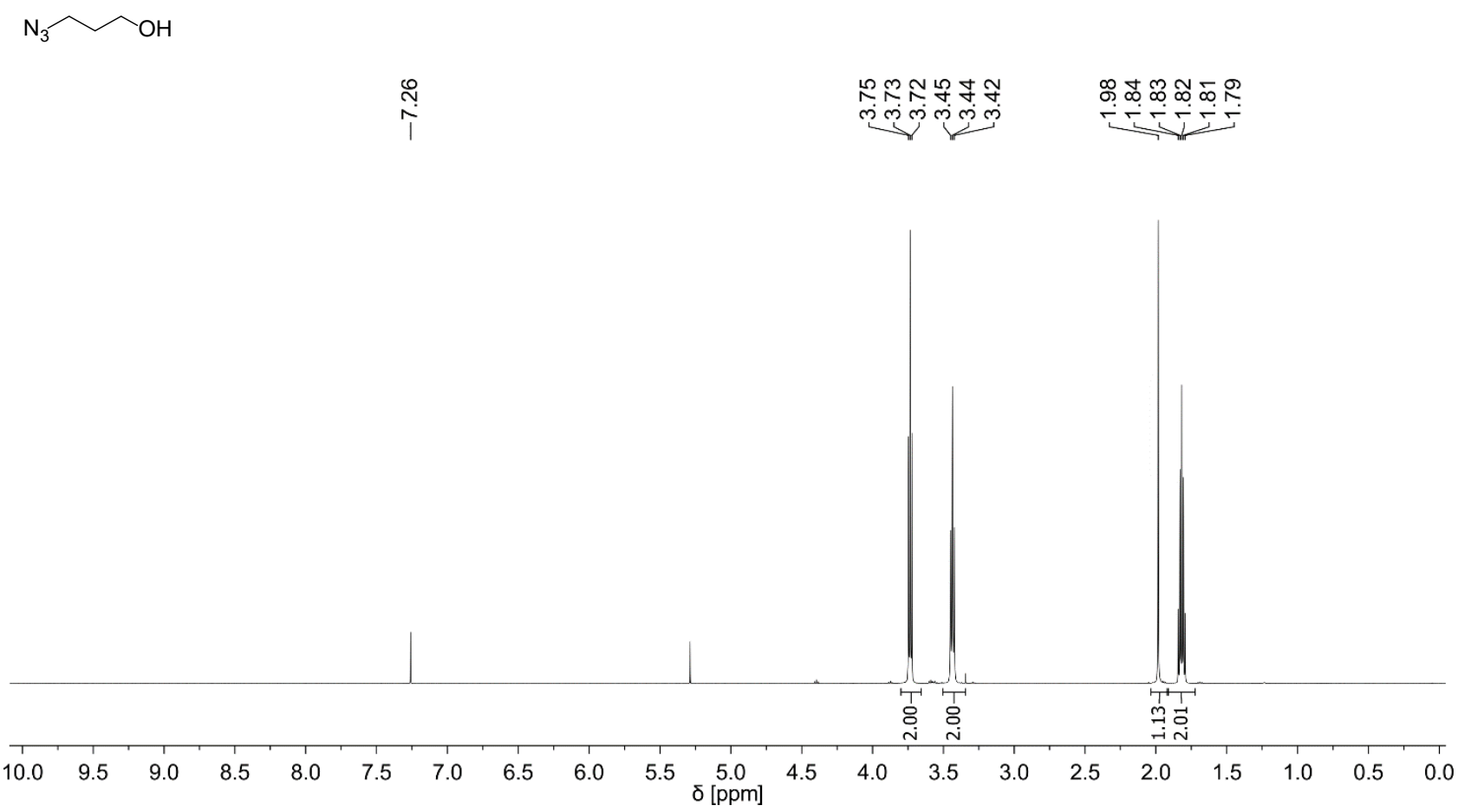

Figure $\mathbf{S 1 .}{ }^{1} \mathbf{H}-\mathbf{N M R}\left(500 \mathrm{MHz}, \mathrm{CDCl}_{3}\right)$ of $\mathbf{S 5}$.

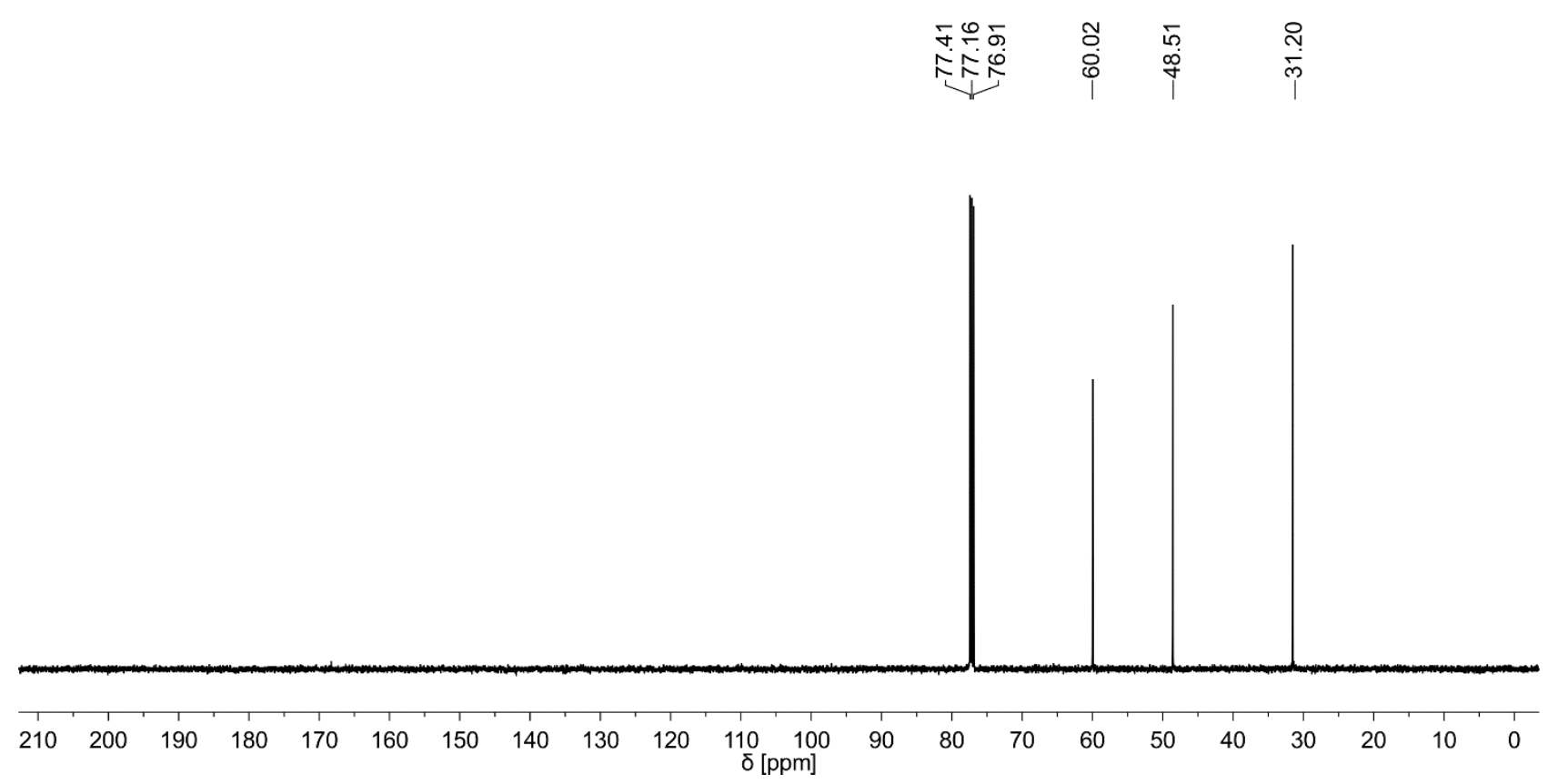

Figure S2. ${ }^{13} \mathbf{C}-\mathbf{N M R}\left(126 \mathrm{MHz}, \mathrm{CDCl}_{3}\right)$ of $\mathbf{S 5}$. 


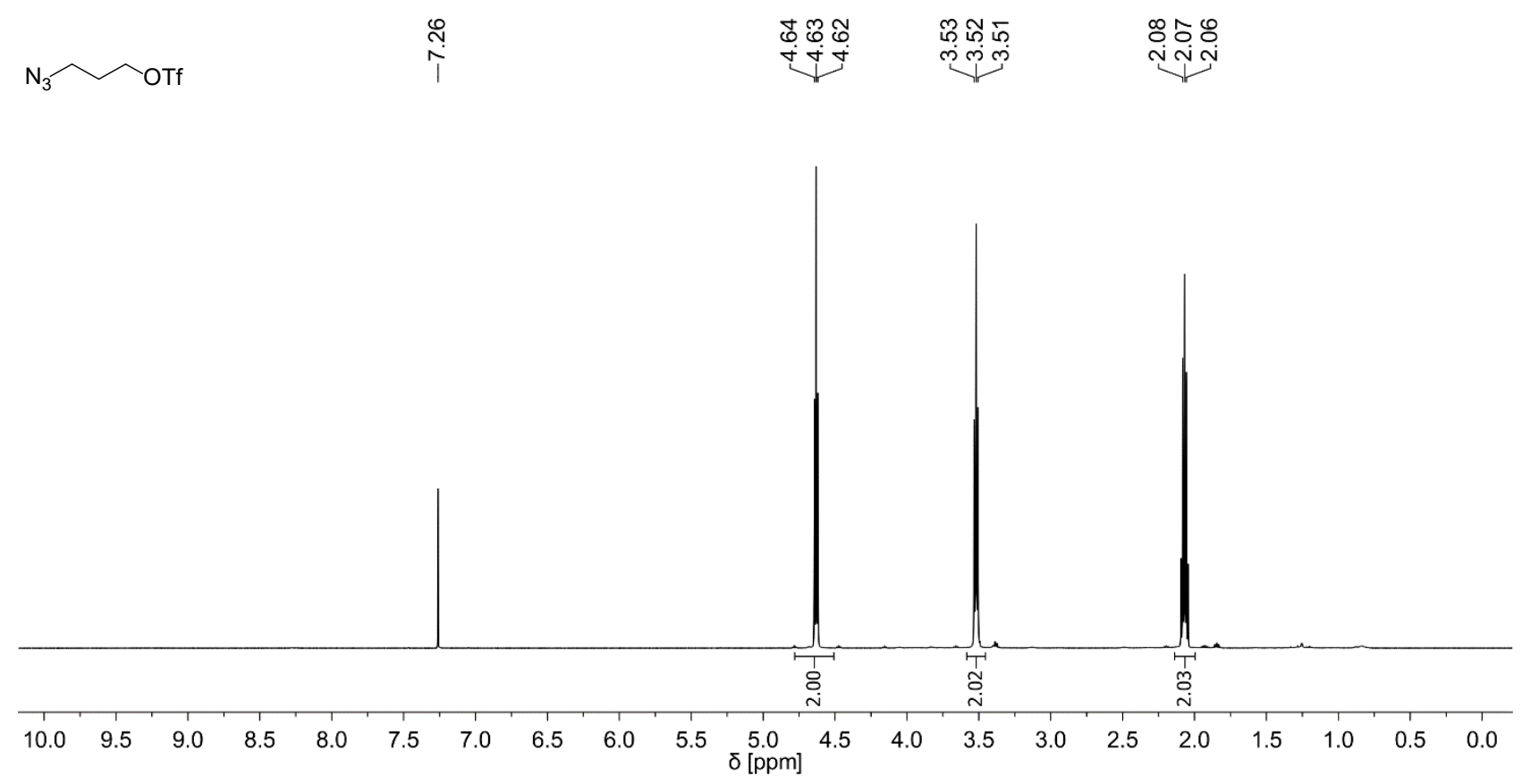

Figure S3. ${ }^{1} \mathbf{H}-\mathrm{NMR}\left(500 \mathrm{MHz}, \mathrm{CDCl}_{3}\right)$ of $\mathbf{S 6}$.

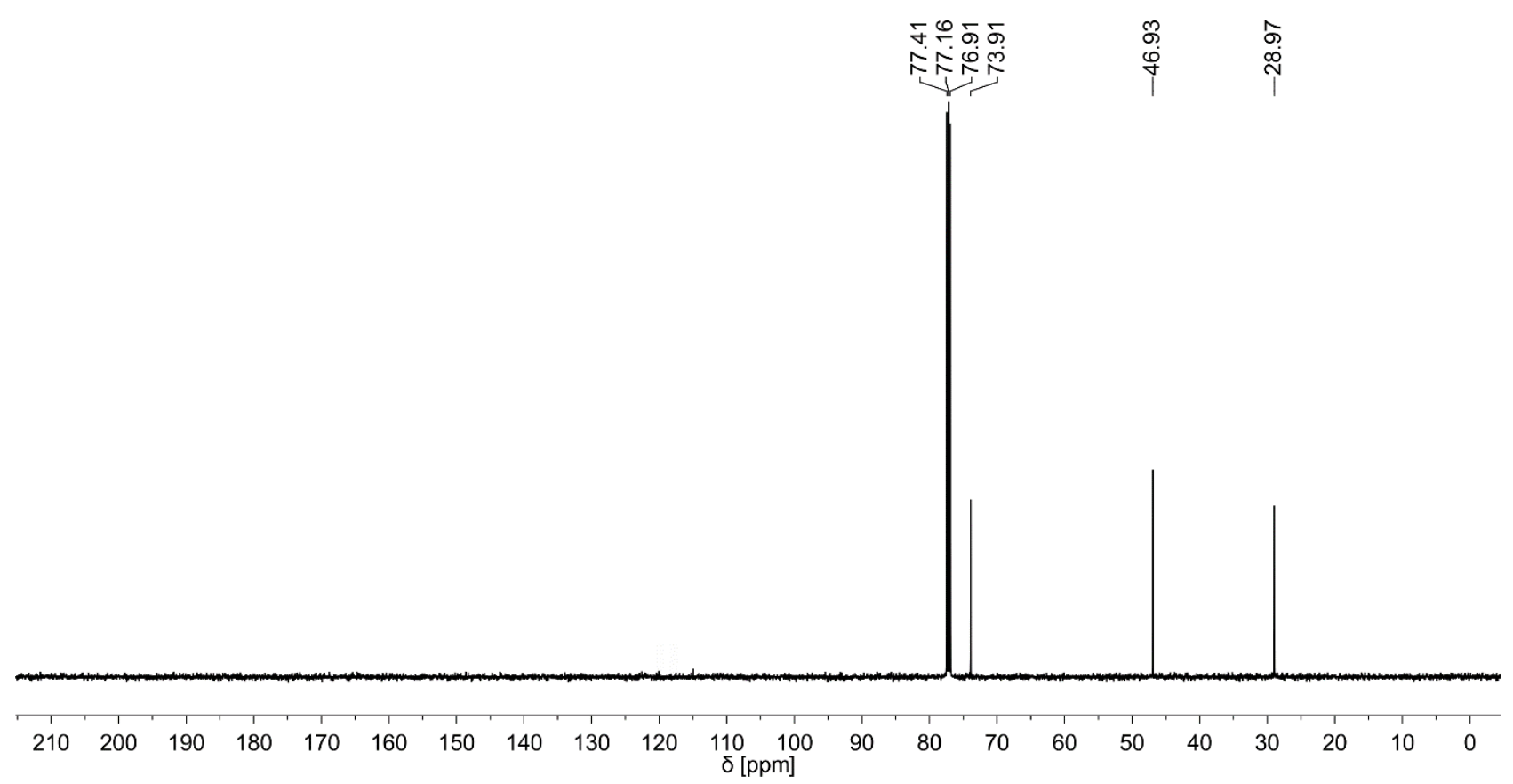

Figure S4. ${ }^{13} \mathbf{C}$-NMR (126 MHz, $\left.\mathrm{CDCl}_{3}\right)$ of $\mathbf{S 6}$. 


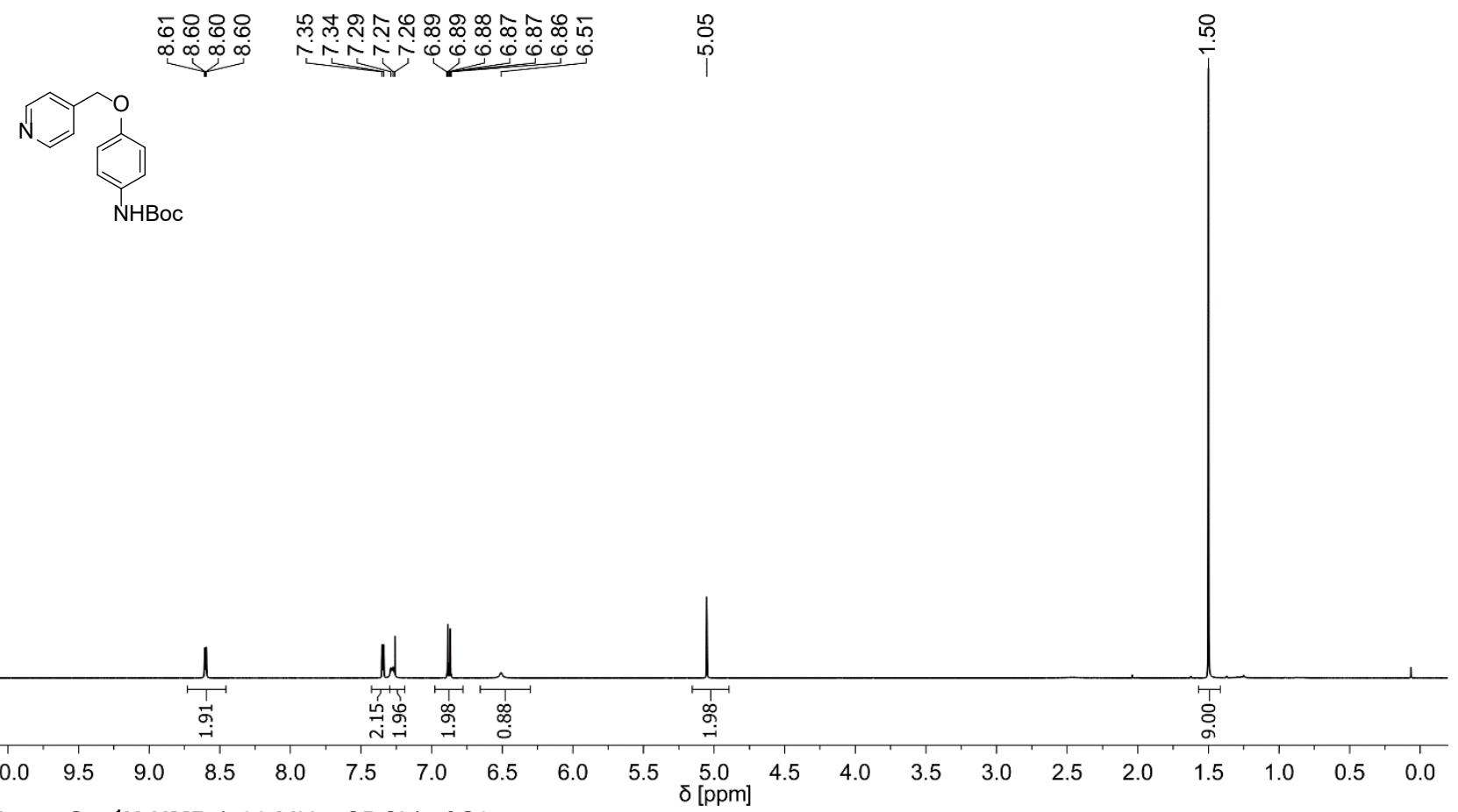

Figure S5. ${ }^{1} \mathbf{H}-\mathbf{N M R}\left(500 \mathrm{MHz}, \mathrm{CDCl}_{3}\right)$ of $\mathbf{S 3}$.

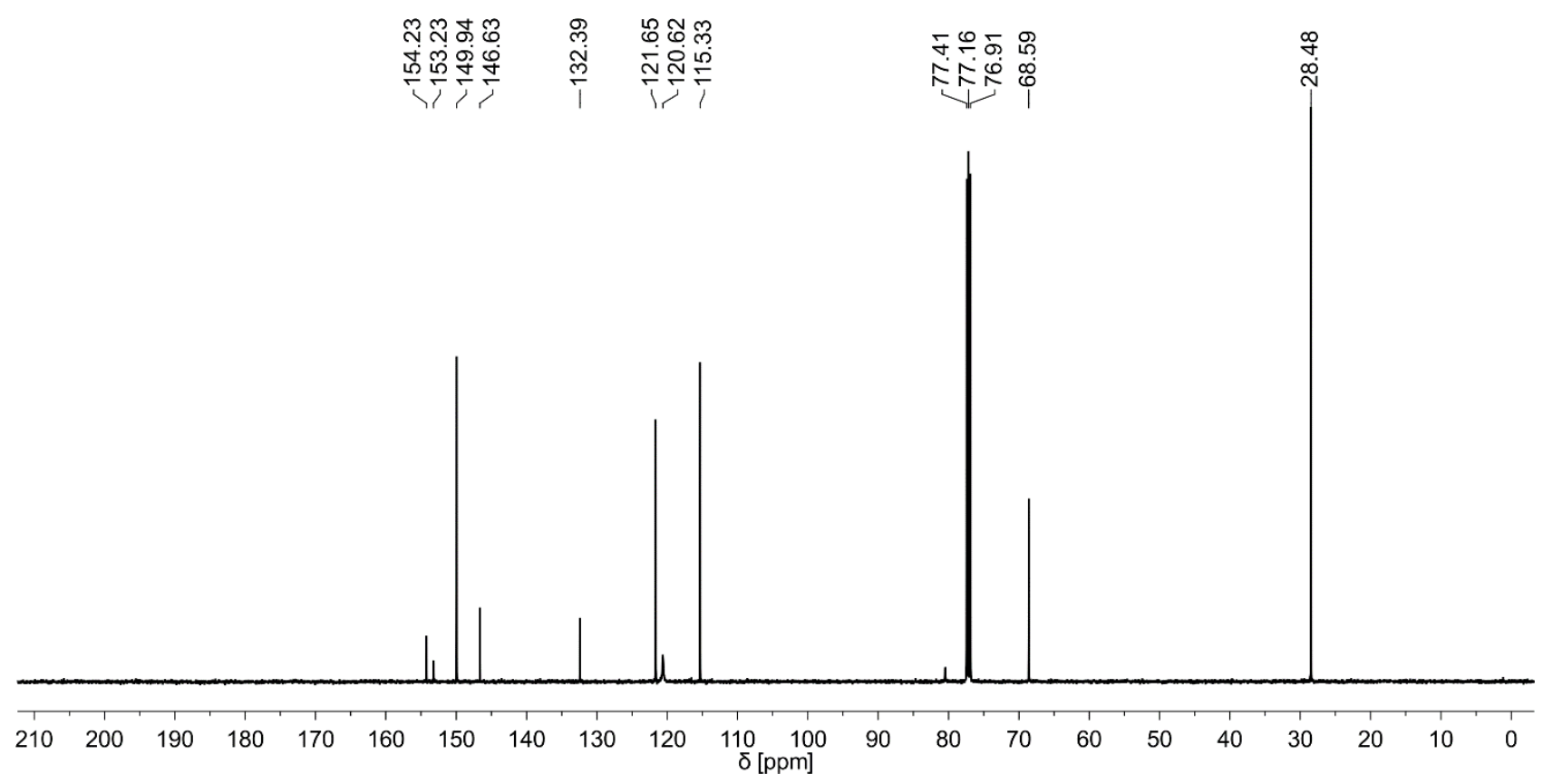

Figure S6. ${ }^{13} \mathbf{C}-\mathrm{NMR}\left(126 \mathrm{MHz}, \mathrm{CDCl}_{3}\right)$ of $\mathbf{S 3}$. 


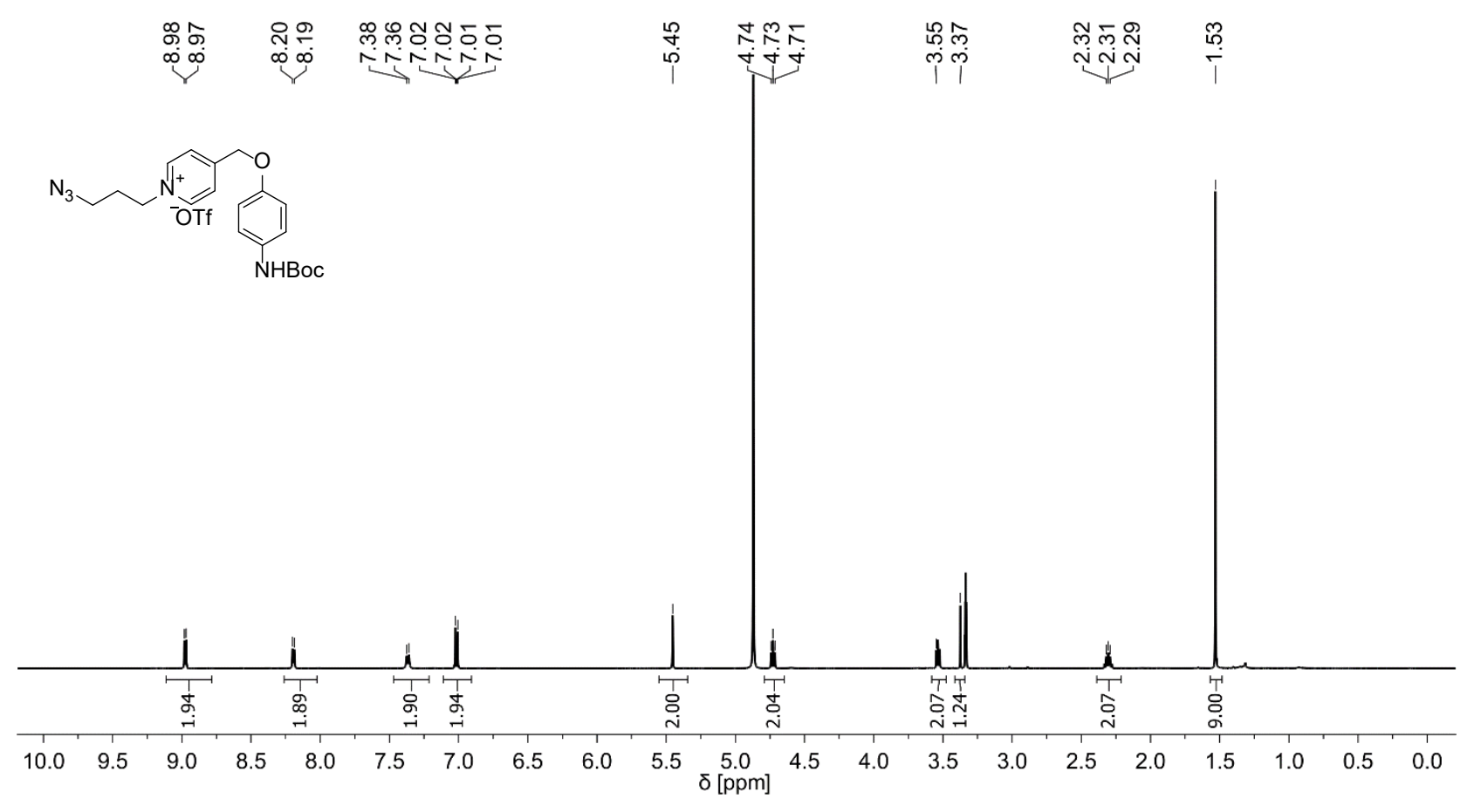

Figure S7. ${ }^{1} \mathbf{H}-\mathrm{NMR}(500 \mathrm{MHz}, \mathrm{MeOD}-\mathrm{d} 4)$ of $\mathbf{S 7 .}$

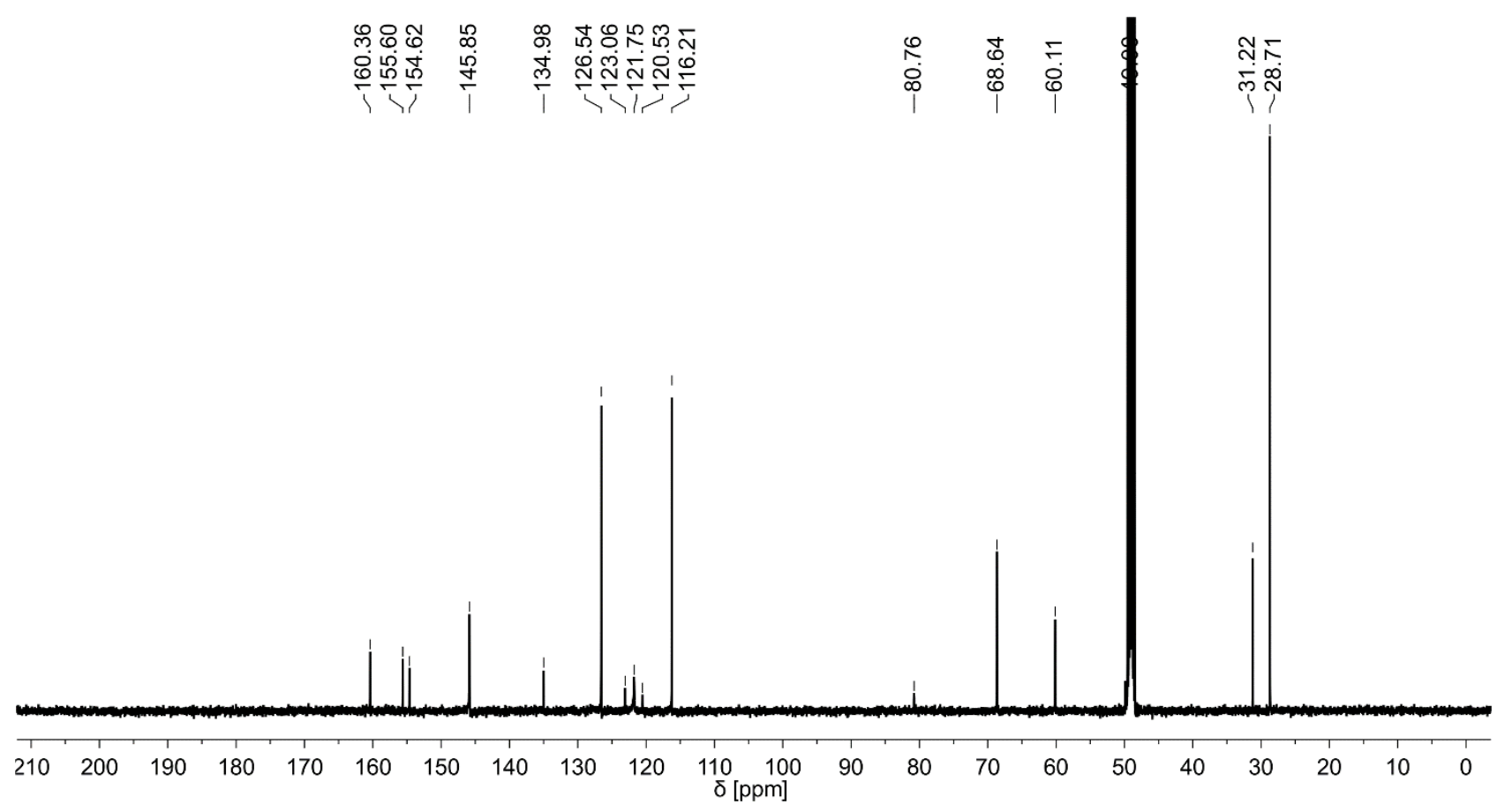

Figure S8. ${ }^{13} \mathrm{C}-\mathrm{NMR}(126 \mathrm{MHz}, \mathrm{MeOD}-\mathrm{d} 4)$ of S7. 


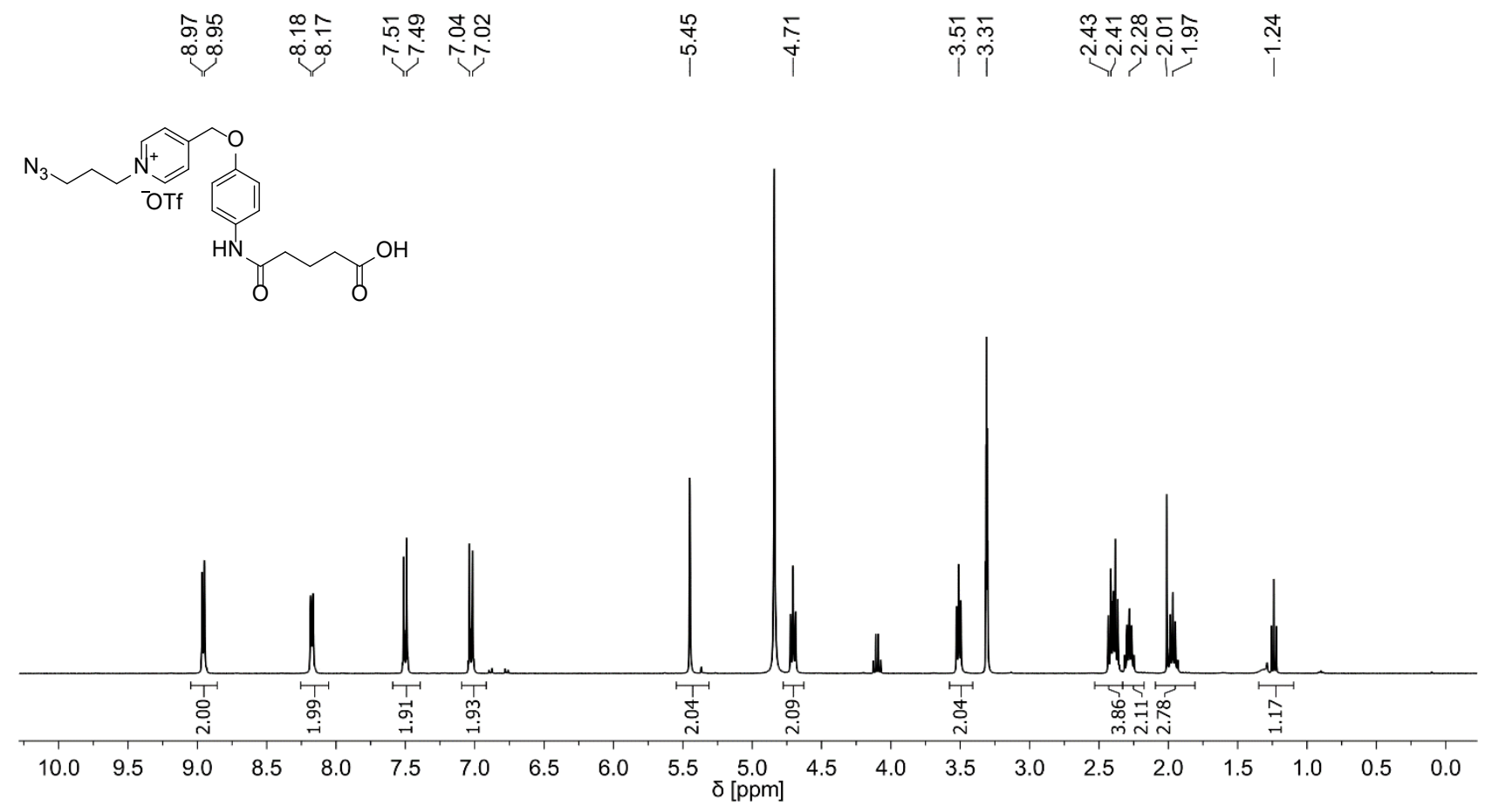

Figure S9. 'H-NMR (500 MHz, MeOD-d4) of 13.

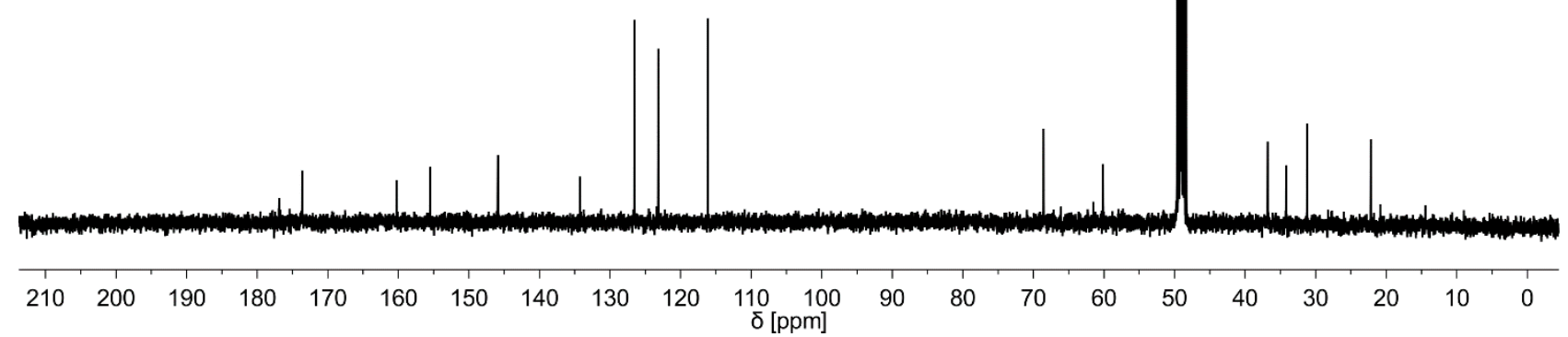

Figure S10. ${ }^{13} \mathrm{C}-\mathrm{NMR}(126 \mathrm{MHz}, \mathrm{MeOD}-\mathrm{d} 4)$ of 13. 

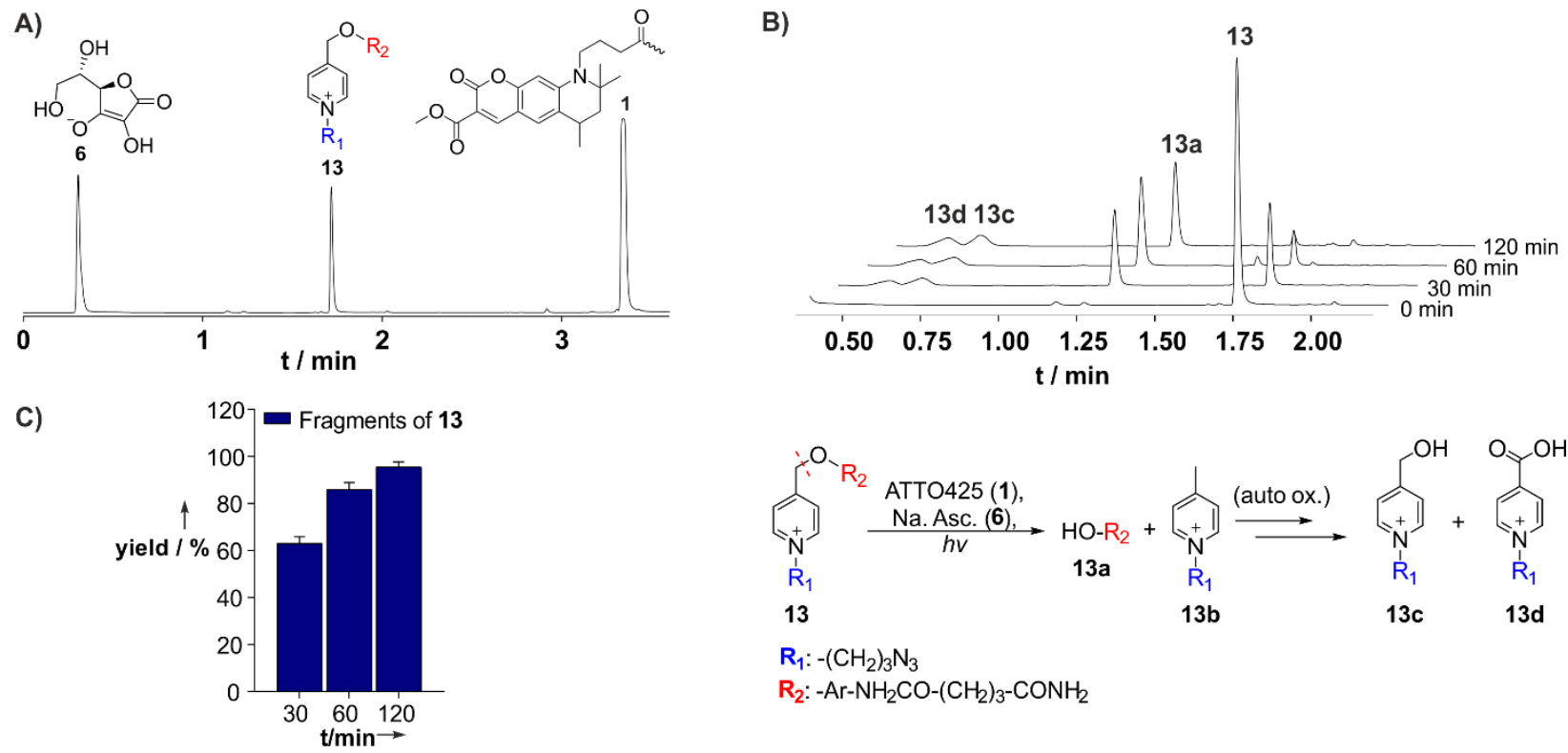

$\mathbf{R}_{\mathbf{1}}:-\left(\mathrm{CH}_{2}\right)_{3} \mathrm{~N}_{3}$

$\mathrm{R}_{2}$ : $-\mathrm{Ar}-\mathrm{NH}_{2} \mathrm{CO}-\left(\mathrm{CH}_{2}\right)_{3}-\mathrm{CONH}_{2}$

Figure S11. Photo triggered cleavage of 13. A) UPLC-trace before irradiation and B) close-up after 30,60 and $120 \mathrm{~min}$; C) calculated yields (integration of peaks). Conditions: $500 \mu \mathrm{M} \mathrm{13,2.5} \mathrm{mM} \mathrm{ATTO425} \mathrm{in} \mathrm{buffer} \mathrm{(10} \mathrm{mM} \mathrm{NaH} \mathrm{PO}_{4}, 100 \mathrm{mM} \mathrm{NaCl}, 2.5$ $\mathrm{mM} \mathrm{MgCl}_{2}, 10 \mathrm{~mm} \mathrm{Na-Asc.,} \mathrm{pH}=7.4$ ), irradiation at $455 \mathrm{~nm}$.

\subsection{Turn-on (50 nм iMB)}

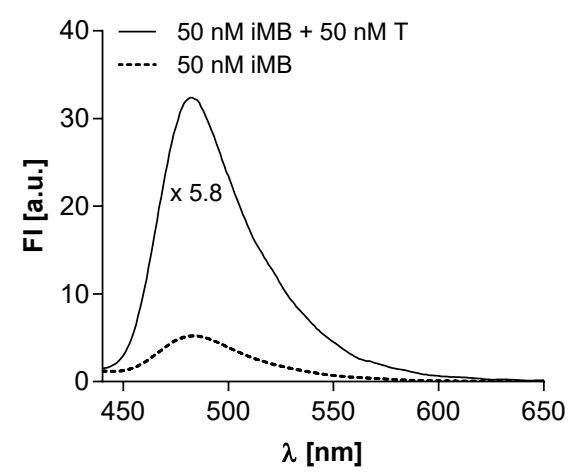

Figure S12. Fluorescence spectra of iMB before (dashed) and after (solid) addition of target T. Conditions: $50 \mathrm{nM}$ iMB, $50 \mathrm{nM}$ T (if added) in PBS buffer (10 mM NaH $\mathrm{PO}_{4}, 100 \mathrm{mM} \mathrm{NaCl}, 2.5 \mathrm{mM} \mathrm{MgCl}, 5 \mathrm{mM} \mathrm{Asc}$., $\left.\mathrm{pH}=7.4\right), \mathrm{T}=37^{\circ} \mathrm{C}$.

\subsection{Photobleaching of ATTO425}

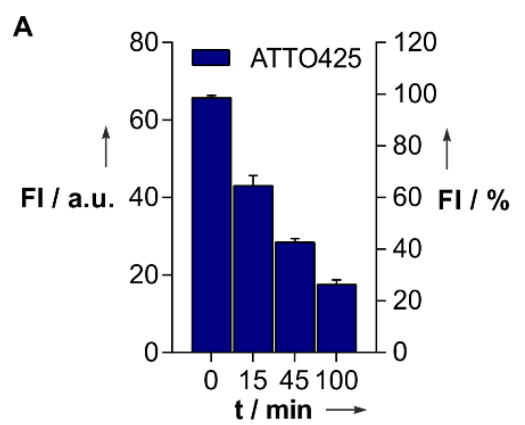

Figure S13. A) Photobleaching of ATTO425 (50 nM) in PBS buffer (10 mM NaH $\mathrm{PO}_{4}, 100 \mathrm{~mm} \mathrm{NaCl}, 2.5 \mathrm{mM} \mathrm{MgCl} 2, \mathrm{pH}=7.4$ ) upon irradiation at $455 \mathrm{~nm}$ for indicated time points. Read out in $1000 \mu \mathrm{L}$ Quartz cuvettes. 


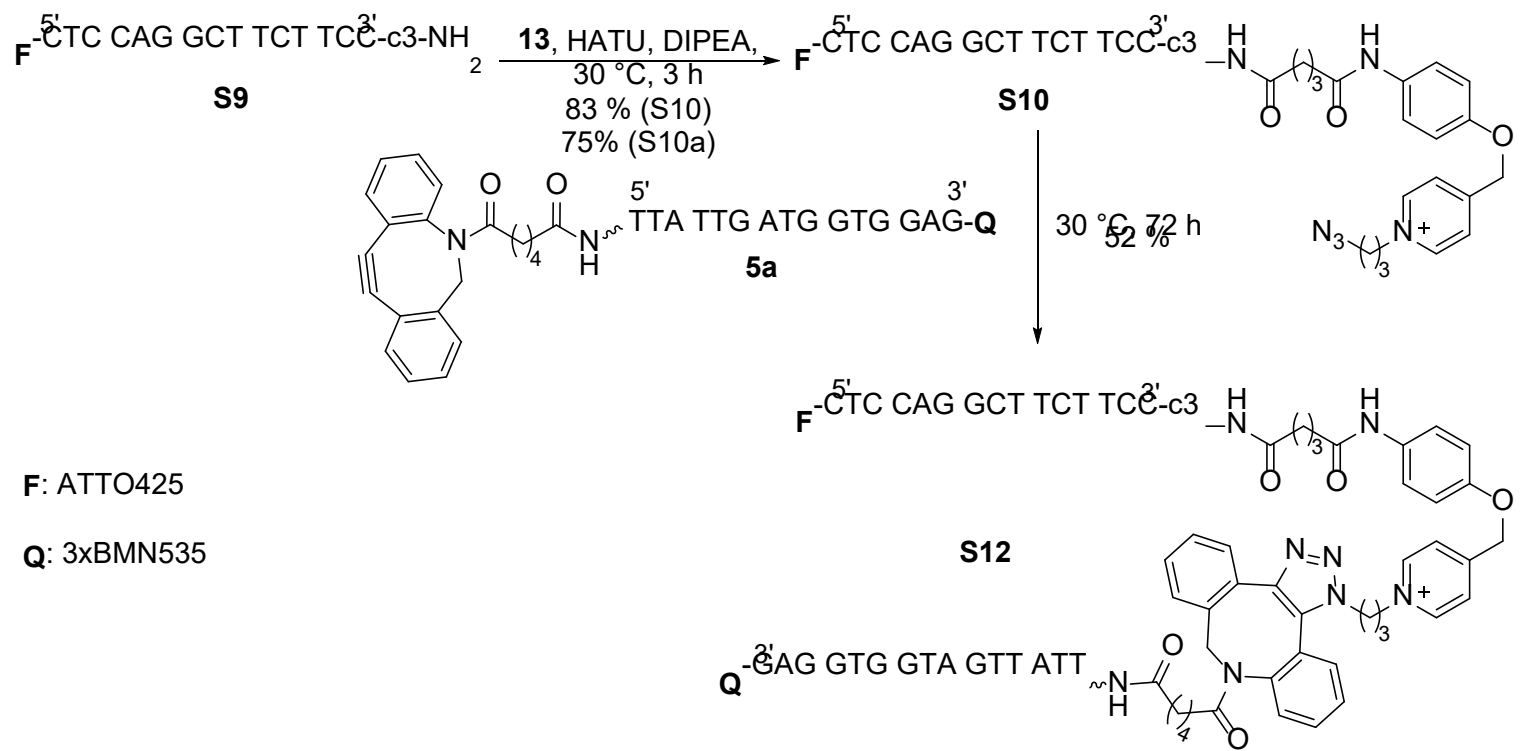

Scheme S2. Synthesis of iMB S12

\subsubsection{S10}

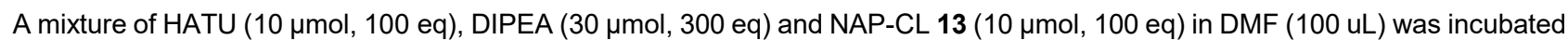
for $4 \mathrm{~min}$. Subsequently, the reaction mixture was transferred to a $2 \mathrm{~mL}$ Sarstedt microtube containing oligonucleotide S9 (100 $\mathrm{nmol}, 1 \mathrm{eq}$ ) in $200 \mu \mathrm{L}$ water. The mixture was agitated for $3 \mathrm{~h}$ at $25^{\circ} \mathrm{C}$. The oligonucleotide was precipitated with iPrOH, vortexed and left for quantitative precipitation at $-18{ }^{\circ} \mathrm{C}$ for $3 \mathrm{~h}$. After centrifugation (10 min, $\left.13000 \mathrm{rpm}\right)$, the precipitate was dissolved in $100 \mu \mathrm{L}$ water. Next, $3 \mathrm{M}$ sodium acetate $(30 \mu \mathrm{L})$ was added and the crude product was precipitated with iPrOH. After another cooling-period at $-18{ }^{\circ} \mathrm{C}$ for $3 \mathrm{~h}$ the crude was centrifuged and dried over Argon. The oligonucleotide was purified via HPLC. The combined fractions were lyophilized and the residue was desalted via precipitation with ammonium acetate and $\mathrm{iPrOH}$.

\section{ATTO425-CTC CAG GCT TCT TCC-ArO-NAP-N $3($ S10)}

HPLC: $t_{R}=17 \min (10-45 \% B$ in $25 \min )$

UPLC: $\mathrm{t}_{\mathrm{R}}=2.28 \mathrm{~min}(3-60 \% \mathrm{~B}$ in $4 \mathrm{~min})$

MALDI-TOF $(\mathrm{m} / \mathrm{z})$ calcd for: $\mathrm{C}_{207} \mathrm{H}_{275} \mathrm{~N}_{58} \mathrm{O}_{111} \mathrm{P}_{16}: 5845.35[\mathrm{M}+\mathrm{H}]^{+}$, found: $5845.0[\mathrm{M}+\mathrm{H}]^{+}, 5671.9[\mathrm{M}+\mathrm{H}]^{+}(\mathrm{OH}-$

Fragment). Fragmentation of coupled NAP-CL 13 occurs during MALDI-TOF measurement (laser induced)
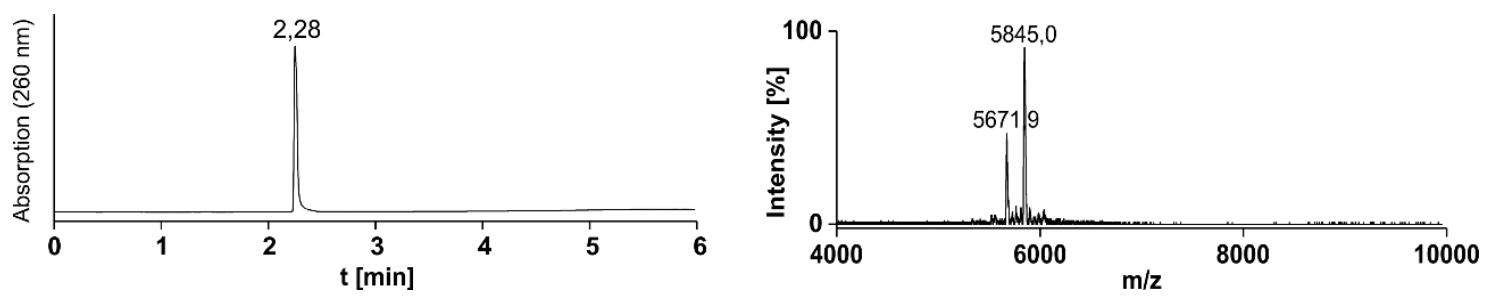

2.6.2 SPAAC (iMB synthesis)

A $2 \mathrm{~mL}$ Sarstedt microtube was charged with a solution of $\mathbf{S 1 0}(20 \mathrm{nmol}, 1 \mathrm{eq})$ in a water/ACN $(1: 1[\mathrm{v} / \mathrm{v}], 50 \mu \mathrm{L})$ mixture. A solution of DBCO-oligonucleotide (5a) $(20 \mathrm{nmol}, 1.0-1.8 \mathrm{eq})$ in a water/ACN $(1: 1$ [v/v], $50 \mu \mathrm{L})$ mixture was added. The solution was agitated for $72 \mathrm{~h}$ at $30^{\circ} \mathrm{C}$. Oligonucleotides were precipitated with $\mathrm{PrOH}$, vortexed and left for quantitative precipitation at $-18^{\circ} \mathrm{C}$ for $3 \mathrm{~h}$. After centrifugation (10 min, $13000 \mathrm{rpm}$ ), the precipitate was dissolved in $100 \mu \mathrm{L}$ water. Next, $3 \mathrm{M}$ sodium acetate $(30 \mu \mathrm{L})$ was added and the crude product was precipitated with $\mathrm{iPrOH}$. After another cooling-period at $-18^{\circ} \mathrm{C}$ for $3 \mathrm{~h}$ the crude was centrifuged and dried over Argon. The oligonucleotide was purified via HPLC. The combined fractions were lyophilized and the residue was desalted via precipitation with ammonium-acetate and $\mathrm{iPrOH}$. 
UPLC: $\mathrm{t}_{\mathrm{R}}=2.72 \mathrm{~min}(3-80 \% \mathrm{~B}$ in $4 \mathrm{~min})$

MALDI-TOF $(\mathrm{m} / \mathrm{z})$ calcd: $12436.2[\mathrm{M}+\mathrm{H}]^{+}$, found: $12436.3[\mathrm{M}+\mathrm{H}]^{+}, 5673.4[\mathrm{M}+\mathrm{H}]^{+}(\mathrm{OH}-$ Fragment $)$. Fragmentation of iMB S12 occurs during MALDI-TOF measurement (laser induced)
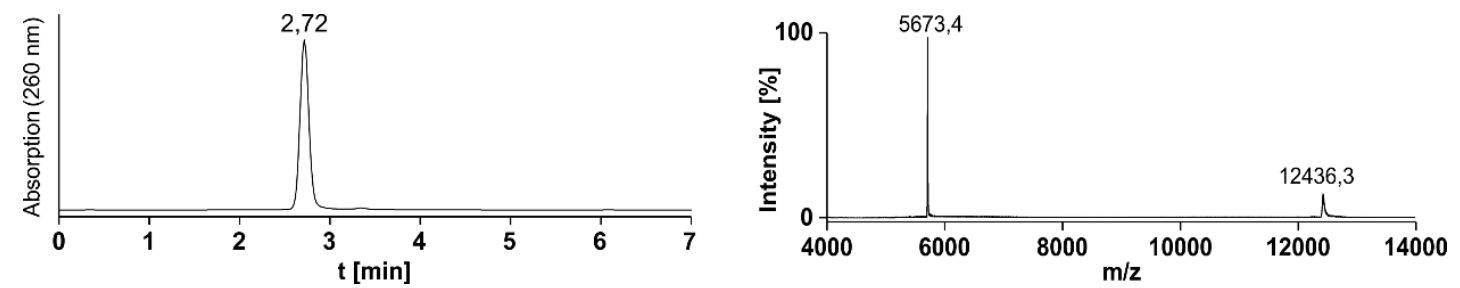

\subsubsection{Target-Sequences}

Table S1. Sequences of the examined targets. Mismatched nucleobases are highlighted.

\begin{tabular}{|c|c|}
\hline Name & Sequence $\left(5^{\prime}-3^{\prime}\right)$ \\
\hline $\mathbf{T}$ & CCA UCA AUA AGG AAG AAG CC \\
\hline$M_{\text {DNA }}$ & CCA TCA ATA AGG AAG AAG CC \\
\hline $1 \mathrm{Mm}$ & CCA UCA AUA AGG $\underline{\mathrm{C}}$ AG AAG CC \\
\hline $2 \mathrm{Mm}$ & CCA $\underline{G} C A$ AUA AGG $\underline{C} A G$ AAG CC \\
\hline Mr & UGC AUC UUG AAA UGU AAU UCG \\
\hline$M_{1 n t}$ & CCA UCA AUA AㅡG GAA GAA GCC \\
\hline$M_{2 n t}$ & CCA UCA AUA ACC GGA AGA AGC C \\
\hline$M_{3 n t}$ & CCA UCA AUA ACG CGG AAG AAG CC \\
\hline $\mathbf{M}_{4 \mathrm{nt}}$ & CCA UCA AUA ACG UCG GAA GAA GCC \\
\hline$M_{5 n t}$ & CCA UCA AUA ACG UCA GGA AGA AGC C \\
\hline$M_{6 n t}$ & CCA UCA AUA ACG UCA CGG AAG AAG CC \\
\hline$M_{7 n t}$ & CCA UCA AUA ACG UCA CAG GAA GAA GCC \\
\hline
\end{tabular}

2.7 Determination of cleavage yield

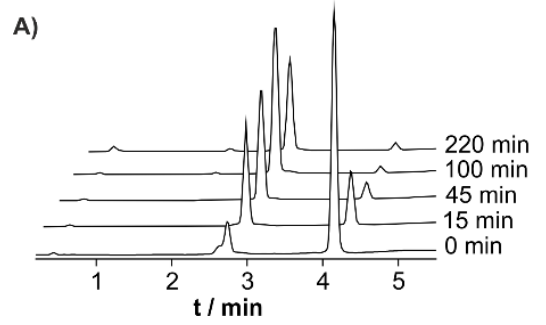

B)

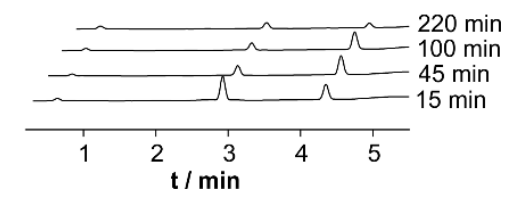

Figure S14. Exemplary UPLC-traces of iMB after photo irradiation in A) presence of 0.1 eq. target $\mathrm{T}$ or $\mathrm{B}$ ) in absence of target. Conditions: $50 \mathrm{nM}$ iMB in PBS buffer $\left(10 \mathrm{mM} \mathrm{NaH}_{2} \mathrm{PO}_{4}, 100 \mathrm{mM} \mathrm{NaCl}, 2.5 \mathrm{mM} \mathrm{MgCl}_{2}, 5 \mathrm{mM}\right.$ Asc. $\left.\mathrm{pH}=7.4\right), \mathrm{T}=37^{\circ} \mathrm{C}$, irradiation at $455 \mathrm{~nm}$. Traces in A) show the growth of the peak at $\mathrm{rt}=2.7 \mathrm{~min}$. This is not observed for traces in $\mathrm{B}$ ). The rather low signal intensity over time in B) may be due to adsorption. 

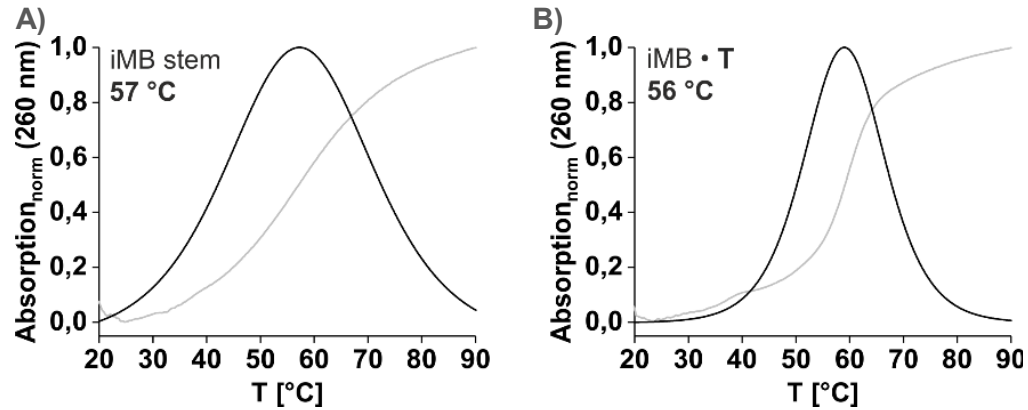

Figure S15. Normalized melting curves of $A$ ) iMB alone and B) after addition of 1 eq $\mathbf{T}$.

A)

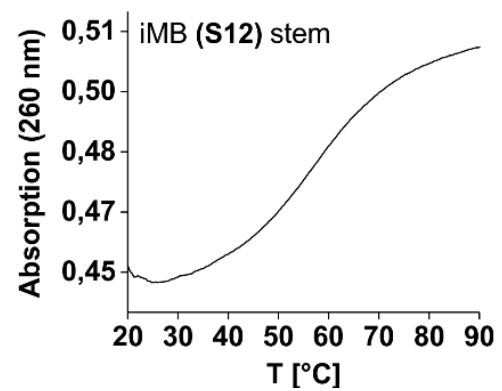

B)

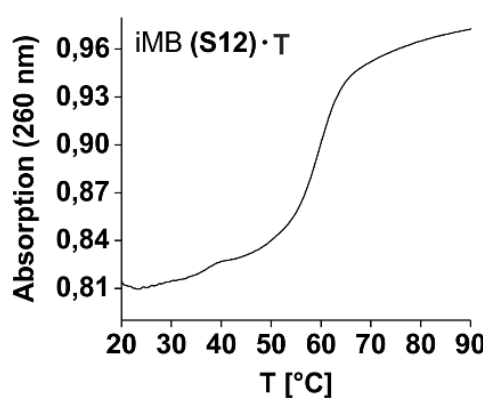

Figure S16. Melting curves of A) iMB alone and B) after addition of 1 eq T.

A)

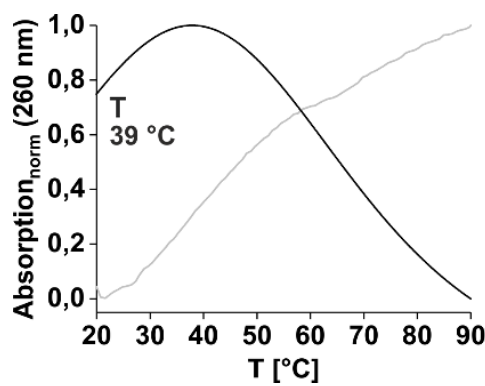

B)

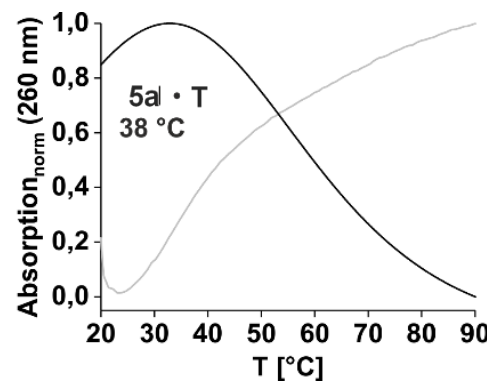

Figure S17. Normalized melting curves of A) T and B) $\mathbf{5 a} \cdot \mathbf{T}$.

A)

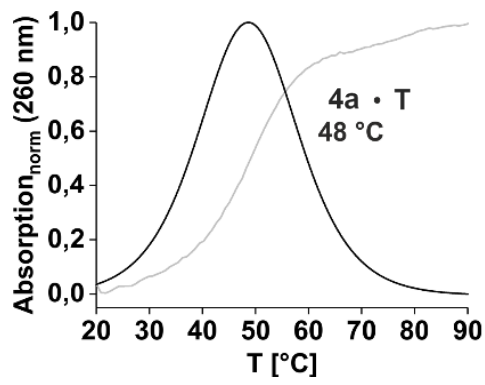

B)

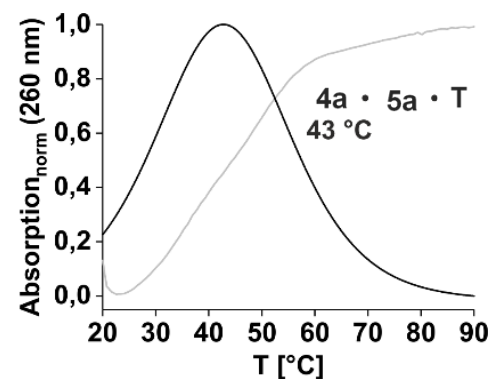

Figure S18. Normalized melting curves of A) $\mathbf{4 a} \cdot \mathbf{T}$ and B) $\mathbf{5 a} \cdot \mathbf{T} \cdot \mathbf{4 a}$. 
2.9 Measurements for limit of detection (LOD)

Table S2. Fluorescence intensities, $F / F_{0}$ and signal change (\%) upon photo irradiation of the iMB in presence of varied amounts of target T. Conditions: $50 \mathrm{nM}$ iMB in PBS buffer (10 $\mathrm{mM} \mathrm{NaH}_{2} \mathrm{PO}_{4}, 100 \mathrm{~mm} \mathrm{NaCl}, 5 \mathrm{~mm}$ Asc., $\left.2.5 \mathrm{mM} \mathrm{MgCl} 2, \mathrm{pH}=7.4\right), \mathrm{T}=37^{\circ} \mathrm{C}$, irradiation at $455 \mathrm{~nm}$.

\begin{tabular}{|c|c|c|c|c|c|c|c|c|c|c|c|c|}
\hline \multirow[t]{2}{*}{ eq $(T)$} & & \multirow{2}{*}{$\begin{array}{c}0 \text { min } \\
\text { FI / a.u. }\end{array}$} & \multicolumn{2}{|c|}{$0 \min +T$} & \multicolumn{2}{|c|}{$15 \mathrm{~min}$} & \multicolumn{2}{|c|}{$45 \mathrm{~min}$} & \multicolumn{2}{|c|}{$100 \mathrm{~min}$} & \multicolumn{2}{|c|}{$220 \mathrm{~min}$} \\
\hline & & & FI / a.u. & $F / F_{0}$ & FI / a.u. & $F / F_{0}$ & FI / a.u. & $F / F_{0}$ & FI / a.u. & $F / F_{0}$ & FI / a.u. & $F / F_{0}$ \\
\hline \multirow[t]{4}{*}{0} & 1 & 3.10 & 3.00 & 0.97 & 2.58 & 0.83 & 2.50 & 0.81 & 2.51 & 0.81 & 2.50 & 0.81 \\
\hline & II & 3.22 & 3.22 & 1.00 & 2.60 & 0.81 & 2.71 & 0.84 & 2.84 & 0.88 & 2.80 & 0.87 \\
\hline & III & 3.20 & 3.30 & 1.03 & 2.60 & 0.81 & 2.66 & 0.83 & 2.78 & 0.87 & 2.60 & 0.81 \\
\hline & avg & $\begin{array}{c}3.17 \\
\pm 0.06 \\
\end{array}$ & $\begin{array}{c}3.17 \\
\pm 0.16 \\
\end{array}$ & $\begin{array}{c}1.00 \\
\pm 0.03 \\
\end{array}$ & $\begin{array}{c}2.59 \\
\pm 0.01 \\
\end{array}$ & $\begin{array}{c}0.82 \\
\pm 0.01 \\
\end{array}$ & $\begin{array}{c}2.62 \\
\pm 0.11 \\
\end{array}$ & $\begin{array}{c}0.82 \\
\pm 0.02 \\
\end{array}$ & $\begin{array}{c}2.71 \\
\pm 0.18 \\
\end{array}$ & $\begin{array}{c}0.85 \\
\pm 0.04 \\
\end{array}$ & $\begin{array}{c}2.63 \\
\pm 0.15 \\
\end{array}$ & $\begin{array}{c}0.83 \\
\pm 0.03 \\
\end{array}$ \\
\hline \multirow[t]{4}{*}{0.002} & 1 & 3.50 & 3.50 & 1.00 & 3.58 & 1.02 & 3.90 & 1.11 & 4.60 & 1.31 & 5.00 & 1.43 \\
\hline & II & 3.50 & 3.59 & 1.03 & 3.59 & 1.03 & 3.79 & 1.08 & 4.20 & 1.20 & 4.96 & 1.42 \\
\hline & III & 3.52 & 3.52 & 1.00 & 3.60 & 1.02 & 3.80 & 1.08 & 4.50 & 1.28 & 4.69 & 1.33 \\
\hline & avg & $\begin{array}{c}3.51 \\
\pm 0.01 \\
\end{array}$ & $\begin{array}{c}3.54 \\
\pm 0.05 \\
\end{array}$ & $\begin{array}{c}1.01 \\
\pm 0.01 \\
\end{array}$ & $\begin{array}{c}3.59 \\
\pm 0.01 \\
\end{array}$ & $\begin{array}{c}1.02 \\
\pm 0.01 \\
\end{array}$ & $\begin{array}{c}3.83 \\
\pm 0.06 \\
\end{array}$ & $\begin{array}{c}1.09 \\
\pm 0.02 \\
\end{array}$ & $\begin{array}{c}4.43 \\
\pm 0.21 \\
\end{array}$ & $\begin{array}{c}1.26 \\
\pm 0.06 \\
\end{array}$ & $\begin{array}{c}4.88 \\
\pm 0.17 \\
\end{array}$ & $\begin{array}{c}1.97 \\
\pm 0.08 \\
\end{array}$ \\
\hline \multirow[t]{4}{*}{0.005} & 1 & 4.20 & 4.35 & 1.04 & 5.20 & 1.24 & 5.70 & 1.36 & 6.20 & 1.48 & 6.50 & 1.55 \\
\hline & II & 4.02 & 4.30 & 1.07 & 5.00 & 1.24 & 5.70 & 1.42 & 6.40 & 1.59 & 6.70 & 1.67 \\
\hline & III & 3.70 & 3.80 & 1.03 & 4.30 & 1.16 & 4.97 & 1.34 & 5.40 & 1.46 & 6.30 & 1.70 \\
\hline & avg & $\begin{array}{c}3.97 \\
\pm 0.25 \\
\end{array}$ & $\begin{array}{c}4.15 \\
\pm 0.30 \\
\end{array}$ & $\begin{array}{c}1.04 \\
\pm 0.02 \\
\end{array}$ & $\begin{array}{c}4.83 \\
\pm 0.47 \\
\end{array}$ & $\begin{array}{c}1.21 \\
\pm 0.05 \\
\end{array}$ & $\begin{array}{c}5.46 \\
\pm 0.42 \\
\end{array}$ & $\begin{array}{c}1.37 \\
\pm 0.04 \\
\end{array}$ & $\begin{array}{c}6.00 \\
\pm 0.53 \\
\end{array}$ & $\begin{array}{c}1.51 \\
\pm 0.07 \\
\end{array}$ & $\begin{array}{c}6.50 \\
\pm 0.20 \\
\end{array}$ & $\begin{array}{c}1.64 \\
\pm 0.08 \\
\end{array}$ \\
\hline \multirow[t]{4}{*}{0.01} & 1 & 3.35 & 3.55 & 1.06 & 4.92 & 1.47 & 5.90 & 1.76 & 6.24 & 1.86 & 7.40 & 2.21 \\
\hline & II & 3.42 & 3.68 & 1.08 & 4.59 & 1.34 & 5.34 & 1.56 & 6.05 & 1.77 & 7.69 & 2.25 \\
\hline & III & 3.40 & 3.70 & 1.09 & 4.14 & 1.22 & 4.90 & 1.44 & 5.22 & 1.54 & 5.20 & 1.54 \\
\hline & avg & $\begin{array}{c}3.39 \\
\pm 0.04 \\
\end{array}$ & $\begin{array}{c}3.64 \\
\pm 0.08 \\
\end{array}$ & $\begin{array}{c}1.07 \\
\pm 0.05 \\
\end{array}$ & $\begin{array}{c}4.55 \\
\pm 0.39 \\
\end{array}$ & $\begin{array}{c}1.34 \\
\pm 0.13 \\
\end{array}$ & $\begin{array}{c}5.38 \\
\pm 0.50 \\
\end{array}$ & $\begin{array}{c}1.59 \\
\pm 0.16 \\
\end{array}$ & $\begin{array}{c}5.84 \\
\pm 0.54 \\
\end{array}$ & $\begin{array}{c}1.72 \\
\pm 0.17 \\
\end{array}$ & $\begin{array}{c}6.76 \\
\pm 1.36 \\
\end{array}$ & $\begin{array}{r}1.72 \\
\pm 0.40 \\
\end{array}$ \\
\hline \multirow[t]{4}{*}{0.02} & I & 3.10 & 3.56 & 1.15 & 5.00 & 1.61 & 6.15 & 1.98 & 6.58 & 2.12 & 7.40 & 2.39 \\
\hline & II & 3.47 & 3.82 & 1.10 & 4.87 & 1.40 & 5.94 & 1.71 & 6.89 & 1.99 & 9.00 & 2.59 \\
\hline & III & 3.10 & 3.38 & 1.09 & 4.30 & 1.39 & 5.00 & 1.61 & 5.38 & 1.74 & 5.40 & 1.74 \\
\hline & avg & $\begin{array}{c}3.22 \\
\pm 0.21\end{array}$ & $\begin{array}{c}3.59 \\
\pm 0.22\end{array}$ & $\begin{array}{c}1.11 \\
\pm 0.03\end{array}$ & $\begin{array}{c}4.72 \\
\pm 0.37\end{array}$ & $\begin{array}{c}1.47 \\
\pm 0.13\end{array}$ & $\begin{array}{c}5.67 \\
\pm 0.61\end{array}$ & $\begin{array}{c}1.77 \\
\pm 0.19\end{array}$ & $\begin{array}{c}6.28 \\
\pm 0.79\end{array}$ & $\begin{array}{c}1.95 \\
\pm 0.20\end{array}$ & $\begin{array}{c}7.27 \\
\pm 1.80\end{array}$ & $\begin{array}{c}2.24 \\
\pm 0.44\end{array}$ \\
\hline \multirow[t]{4}{*}{0.1} & I & 4.10 & 6.37 & 1.55 & 8.20 & 2.00 & 10.17 & 2.48 & 9.66 & 2.36 & 10.02 & 2.44 \\
\hline & II & 3.37 & 5.00 & 1.48 & 6.90 & 2.05 & 8.40 & 2.49 & 8.70 & 2.58 & 8.40 & 2.49 \\
\hline & III & 3.80 & 5.77 & 1.52 & 7.51 & 1.98 & 9.31 & 2.45 & 9.38 & 2.47 & 9.40 & 2.47 \\
\hline & avg & $\begin{array}{c}3.76 \\
\pm 0.37 \\
\end{array}$ & $\begin{array}{c}5.71 \\
\pm 0.69 \\
\end{array}$ & $\begin{array}{c}1.52 \\
\pm 0.03 \\
\end{array}$ & $\begin{array}{c}7.54 \\
\pm 0.65 \\
\end{array}$ & $\begin{array}{c}2.01 \\
\pm 0.04 \\
\end{array}$ & $\begin{array}{c}9.25 \\
\pm 0.49 \\
\end{array}$ & $\begin{array}{c}2.47 \\
\pm 0.02 \\
\end{array}$ & $\begin{array}{c}9.25 \\
\pm 0.49 \\
\end{array}$ & $\begin{array}{c}2.47 \\
\pm 0.11 \\
\end{array}$ & $\begin{array}{c}9.27 \\
\pm 0.82 \\
\end{array}$ & $\begin{array}{c}2.47 \\
\pm 0.02 \\
\end{array}$ \\
\hline \multirow[t]{4}{*}{1.0} & 1 & 4.50 & 25.70 & 5.71 & & & & & & & & \\
\hline & II & 4.80 & 25.60 & 5.33 & & & & & & & & \\
\hline & III & 5.10 & 33.10 & 6.49 & & & & & & & & \\
\hline & avg & $\begin{array}{c}4.80 \\
\pm 0.30\end{array}$ & $\begin{array}{r}28.13 \\
\pm 4.30\end{array}$ & $\begin{array}{c}5.84 \\
\pm 0.59\end{array}$ & & & & & & & & \\
\hline
\end{tabular}


Table S3. Fluorescence intensities, $\mathrm{F} / \mathrm{F}_{0}$ and signal change $(\%)$ upon photo irradiation of the iMB in presence of varied amounts of target T. Conditions: $50 \mathrm{nM}$ iMB in PBS buffer (10 mM NaH${ }_{2} \mathrm{PO}_{4}, 100 \mathrm{~mm} \mathrm{NaCl}, 5 \mathrm{~mm} \mathrm{Asc}$., $2.5 \mathrm{~mm} \mathrm{MgCl}, 0.001 \%$ Tween20, $\mathrm{pH}=7.4), \mathrm{T}=37^{\circ} \mathrm{C}$, irradiation at $455 \mathrm{~nm}$.

\begin{tabular}{|c|c|c|c|c|c|c|c|c|c|c|c|c|}
\hline \multirow[t]{2}{*}{ eq $(T)$} & & \multirow{2}{*}{$\begin{array}{c}0 \mathrm{~min} \\
\mathrm{FI} / \mathrm{a} . \mathrm{u} .\end{array}$} & \multicolumn{2}{|c|}{$0 \mathrm{~min}+\mathrm{T}$} & \multicolumn{2}{|c|}{$15 \mathrm{~min}$} & \multicolumn{2}{|c|}{$45 \mathrm{~min}$} & \multicolumn{2}{|c|}{$100 \mathrm{~min}$} & \multicolumn{2}{|c|}{$220 \mathrm{~min}$} \\
\hline & & & FI / a.u. & $F / F_{0}$ & FI / a.u. & $F / F_{0}$ & FI / a.u. & $F / F_{0}$ & FI / a.u. & $F / F_{0}$ & FI / a.u. & $F / F_{0}$ \\
\hline \multirow[t]{4}{*}{0} & 1 & 3.66 & 3.66 & 1.00 & 3.56 & 0.97 & 4.10 & 1.12 & 4.48 & 1.22 & 5.90 & 1.61 \\
\hline & II & 3.70 & 3.70 & 1.00 & 3.60 & 0.97 & 4.61 & 1.24 & 4.68 & 1.26 & 5.10 & 1.38 \\
\hline & III & 3.70 & 3.70 & 1.00 & 3.00 & 0.81 & 3.70 & 1.00 & 4.40 & 1.19 & 5.20 & 1.41 \\
\hline & avg & $\begin{array}{c}3.69 \\
\pm 0.02 \\
\end{array}$ & $\begin{array}{c}3.69 \\
\pm 0.02 \\
\end{array}$ & $\begin{array}{l}1.00 \\
\pm 0 \\
\end{array}$ & $\begin{array}{c}3.39 \\
\pm 0.34 \\
\end{array}$ & $\begin{array}{c}0.92 \\
\pm 0.09 \\
\end{array}$ & $\begin{array}{c}4.13 \\
\pm 0.45 \\
\end{array}$ & $\begin{array}{c}1.12 \\
\pm 0.12 \\
\end{array}$ & $\begin{array}{r}4.52 \\
\pm 0.14 \\
\end{array}$ & $\begin{array}{c}1.22 \\
\pm 0.04 \\
\end{array}$ & $\begin{array}{c}5.40 \\
\pm 0.44 \\
\end{array}$ & $\begin{array}{c}1.47 \\
\pm 0.13 \\
\end{array}$ \\
\hline \multirow[t]{4}{*}{0.0001} & 1 & 3.50 & 3.50 & 1.00 & 3.80 & 1.09 & 4.60 & 1.31 & 5.60 & 1.60 & 6.00 & 1.71 \\
\hline & II & 3.81 & 3.81 & 1.00 & 4.08 & 1.07 & 4.77 & 1.26 & 5.50 & 1.45 & 6.00 & 1.58 \\
\hline & III & 3.80 & 3.75 & 0.99 & 3.85 & 1.01 & 4.70 & 1.24 & 5.70 & 1.50 & 6.70 & 1.76 \\
\hline & avg & $\begin{array}{c}3.70 \\
\pm 0.17 \\
\end{array}$ & $\begin{array}{c}3.68 \pm \\
0.16\end{array}$ & $\begin{array}{c}1.00 \pm \\
0.01\end{array}$ & $\begin{array}{c}3.91 \pm \\
0.15\end{array}$ & $\begin{array}{c}1.06 \\
\pm 0.04 \\
\end{array}$ & $\begin{array}{c}4.69 \\
\pm 0.09 \\
\end{array}$ & $\begin{array}{c}1.27 \\
\pm 0.04 \\
\end{array}$ & $\begin{array}{c}5.60 \\
\pm 0.10 \\
\end{array}$ & $\begin{array}{c}1.52 \\
\pm 0.08 \\
\end{array}$ & $\begin{array}{c}6.23 \\
\pm 0.40 \\
\end{array}$ & $\begin{array}{r}1.69 \\
\pm 0.10 \\
\end{array}$ \\
\hline \multirow[t]{4}{*}{0.0002} & I & 3.50 & 3.50 & 1.00 & 3.80 & 1.09 & 4.81 & 1.37 & 5.60 & 1.60 & 6.00 & 1.71 \\
\hline & II & 3.80 & 3.85 & 1.01 & 4.13 & 1.09 & 4.92 & 1.30 & 5.70 & 1.50 & 6.20 & 1.63 \\
\hline & III & 3.76 & 3.81 & 1.01 & 4.20 & 1.12 & 5.10 & 1.36 & 6.01 & 1.60 & 6.70 & 1.78 \\
\hline & avg & $\begin{array}{c}3.69 \\
\pm 0.16 \\
\end{array}$ & $\begin{array}{r}3.72 \\
\pm 0.19 \\
\end{array}$ & $\begin{array}{r}1.01 \\
\pm 0.01 \\
\end{array}$ & $\begin{array}{c}4.04 \\
\pm 0.21 \\
\end{array}$ & $\begin{array}{c}1.10 \\
\pm 0.02 \\
\end{array}$ & $\begin{array}{c}4.94 \\
\pm 0.15 \\
\end{array}$ & $\begin{array}{r}1.34 \\
\pm 0.04 \\
\end{array}$ & $\begin{array}{c}5.77 \\
\pm 0.21 \\
\end{array}$ & $\begin{array}{c}1.57 \\
\pm 0.06 \\
\end{array}$ & $\begin{array}{c}6.30 \\
\pm 0.36 \\
\end{array}$ & $\begin{array}{c}1.71 \\
\pm 0.08 \\
\end{array}$ \\
\hline \multirow[t]{4}{*}{0.0005} & 1 & 3.50 & 3.50 & 1.00 & 4.07 & 1.16 & 4.76 & 1.36 & 5.90 & 1.69 & 6.20 & 1.77 \\
\hline & II & 4.04 & 4.04 & 1.00 & 4.60 & 1.14 & 5.77 & 1.43 & 6.89 & 1.71 & 6.90 & 1.71 \\
\hline & III & 3.80 & 3.80 & 1.00 & 4.30 & 1.13 & 5.30 & 1.39 & 6.20 & 1.63 & 7.20 & 1.89 \\
\hline & avg & $\begin{array}{c}3.78 \\
\pm 0.27 \\
\end{array}$ & $\begin{array}{c}3.78 \\
\pm 0.27 \\
\end{array}$ & $\begin{array}{l}1.00 \\
\pm 0 \\
\end{array}$ & $\begin{array}{c}4.32 \\
\pm 0.27 \\
\end{array}$ & $\begin{array}{c}1.14 \\
\pm 0.02 \\
\end{array}$ & $\begin{array}{c}5.28 \\
\pm 0.51 \\
\end{array}$ & $\begin{array}{c}1.39 \\
\pm 0.03 \\
\end{array}$ & $\begin{array}{c}6.33 \\
\pm 0.51 \\
\end{array}$ & $\begin{array}{c}1.67 \\
\pm 0.04 \\
\end{array}$ & $\begin{array}{c}6.77 \\
\pm 0.51 \\
\end{array}$ & $\begin{array}{r}1.79 \\
\pm 0.09 \\
\end{array}$ \\
\hline \multirow[t]{4}{*}{0.001} & 1 & 3.60 & 3.69 & 1.03 & 4.20 & 1.17 & 5.24 & 1.46 & 6.67 & 1.85 & 7.40 & 2.06 \\
\hline & II & 4.20 & 4.13 & 0.98 & 4.90 & 1.17 & 6.17 & 1.47 & 7.89 & 1.88 & 8.20 & 1.95 \\
\hline & III & 3.87 & 4.10 & 1.06 & 4.61 & 1.19 & 5.78 & 1.49 & 6.70 & 1.73 & 7.37 & 1.90 \\
\hline & avg & $\begin{array}{c}3.89 \\
\pm 0.30\end{array}$ & $\begin{array}{c}3.97 \\
\pm 0.25\end{array}$ & $\begin{array}{c}1.02 \\
\pm 0.04\end{array}$ & $\begin{array}{c}4.57 \\
\pm 0.35\end{array}$ & $\begin{array}{c}1.17 \\
\pm 0.01\end{array}$ & $\begin{array}{c}5.73 \\
\pm 0.47\end{array}$ & $\begin{array}{c}1.47 \\
\pm 0.02\end{array}$ & $\begin{array}{c}7.09 \\
\pm 0.70\end{array}$ & $\begin{array}{c}1.82 \\
\pm 0.08\end{array}$ & $\begin{array}{c}7.66 \\
\pm 0.47\end{array}$ & $\begin{array}{c}1.97 \\
\pm 0.08\end{array}$ \\
\hline
\end{tabular}




\subsection{Specificity of iMB signalling}

Table S4. Fluorescence intensities, $F / F_{0}$ and signal change (\%) afforded by iMB prior to and 15 or 100 min after photoirradiation in presence of mismatched RNA. Conditions: $50 \mathrm{nM}$ iMB, $5 \mathrm{nM}$ RNA mix (2Mm, Mr, $\left.\mathbf{M}_{\mathbf{7 n t}}\right)$, PBS buffer (10 mM NaH $\mathrm{PO}_{4}, 100 \mathrm{mM}$ $\mathrm{NaCl}, 2.5 \mathrm{mM} \mathrm{MgCl}_{2}, 5 \mathrm{mM}$ Asc. $\left.\mathrm{pH}=7.4\right), \mathrm{T}=37^{\circ} \mathrm{C}$, irradiation at $455 \mathrm{~nm}$.

\begin{tabular}{|c|c|c|c|c|c|c|c|c|c|c|c|}
\hline \multirow[t]{2}{*}{ eq $(T)$} & & \multirow{2}{*}{$\begin{array}{c}0 \mathrm{~min} \\
\mathrm{FI} / \text { a.u. }\end{array}$} & \multicolumn{3}{|c|}{$0 \min +\mathrm{T}$} & \multicolumn{3}{|c|}{$15 \mathrm{~min}$} & \multicolumn{3}{|c|}{$100 \mathrm{~min}$} \\
\hline & & & FI/ a.u. & $\mathrm{F} / \mathrm{F}_{0}$ & $\begin{array}{c}\text { Signal } \\
\text { change } \\
/ \%\end{array}$ & FI / a.u. & $F / F_{0}$ & $\begin{array}{c}\text { Signal } \\
\text { change } \\
/ \%\end{array}$ & FI / a.u. & $F / F_{0}$ & $\begin{array}{c}\text { Signal } \\
\text { change } \\
/ \%\end{array}$ \\
\hline \multirow[t]{4}{*}{0} & 1 & 6.20 & 6.40 & 1.03 & 3.23 & 5.78 & 0.93 & -6.77 & 6.65 & 1.07 & 7.26 \\
\hline & II & 6.50 & 6.20 & 0.95 & -4.61 & 5.30 & 0.81 & -18.46 & 6.20 & 0.86 & -4.62 \\
\hline & III & 5.80 & 6.00 & 1.03 & 3.44 & 5.70 & 0.87 & -12.59 & 6.60 & 0.98 & 13.79 \\
\hline & avg & $\begin{array}{c}6.12 \pm \\
0.35 \\
\end{array}$ & $\begin{array}{c}6.20 \pm \\
0.20 \\
\end{array}$ & $\begin{array}{c}1.01 \pm \\
0.05 \\
\end{array}$ & $\begin{array}{c}0.67 \pm \\
4.59 \\
\end{array}$ & $\begin{array}{c}5.38 \pm \\
0.36 \\
\end{array}$ & $\begin{array}{c}0.87 \pm \\
0.06 \\
\end{array}$ & $\begin{array}{c}-12.61 \pm \\
5.84\end{array}$ & $\begin{array}{c}6.48 \pm \\
0.25 \\
\end{array}$ & $\begin{array}{c}0.96 \pm \\
0.09 \\
\end{array}$ & $\begin{array}{c}5.48 \pm \\
9.33 \\
\end{array}$ \\
\hline \multirow[t]{4}{*}{0.0025} & 1 & 6.10 & 6.58 & 1.08 & 7.87 & 6.12 & 1.00 & 0.33 & 6.85 & 1.12 & 12.30 \\
\hline & II & 5.78 & 5.78 & 1.00 & 0 & 6.08 & 1.05 & 5.19 & 7.90 & 1.37 & 36.68 \\
\hline & III & 5.60 & 5.70 & 1.02 & 1.79 & 5.80 & 1.04 & 3.57 & 6.18 & 1.10 & 10.36 \\
\hline & avg & $\begin{array}{c}5.83 \pm \\
0.25 \\
\end{array}$ & $\begin{array}{c}6.02 \pm \\
0.49 \\
\end{array}$ & $\begin{array}{c}1.03 \pm \\
0.04 \\
\end{array}$ & $\begin{array}{c}3.22 \pm \\
4.13 \\
\end{array}$ & $\begin{array}{c}6.00 \pm \\
0.17 \\
\end{array}$ & $\begin{array}{c}1.03 \pm \\
0.02 \\
\end{array}$ & $3.03 \pm 2.48$ & $\begin{array}{c}6.98 \pm \\
0.87 \\
\end{array}$ & $\begin{array}{c}1.20 \pm \\
0.15 \\
\end{array}$ & $\begin{array}{c}19.78 \pm \\
14.67\end{array}$ \\
\hline \multirow[t]{4}{*}{0.005} & 1 & 5.35 & 5.90 & 1.10 & 10.28 & 6.24 & 1.17 & 16.64 & 7.72 & 1.44 & 44.30 \\
\hline & II & 5.87 & 6.10 & 1.04 & 3.92 & 6.70 & 1.14 & 14.14 & 7.80 & 1.33 & 32.88 \\
\hline & III & 6.10 & 6.70 & 1.10 & 9.84 & 6.70 & 1.10 & 9.84 & 7.00 & 1.15 & 14.75 \\
\hline & avg & $\begin{array}{c}5.77 \pm \\
0.38\end{array}$ & $\begin{array}{c}6.23 \pm \\
0.42 \\
\end{array}$ & $\begin{array}{c}1.08 \pm \\
0.04\end{array}$ & $\begin{array}{c}8.01 \pm \\
3.55 \\
\end{array}$ & $\begin{array}{c}6.55 \pm \\
0.27 \\
\end{array}$ & $\begin{array}{c}1.14 \pm \\
0.03\end{array}$ & $\begin{array}{c}13.54 \pm \\
3.44\end{array}$ & $\begin{array}{c}7.51 \pm \\
0.44 \\
\end{array}$ & $\begin{array}{c}1.15 \pm \\
0.08\end{array}$ & $\begin{array}{c}14.63 \pm \\
7.54\end{array}$ \\
\hline \multirow[t]{4}{*}{0.01} & 1 & 5.88 & 6.88 & 1.17 & 17.01 & 8.88 & 1.51 & 51.02 & 9.20 & 1.56 & 56.46 \\
\hline & II & 6.59 & 7.70 & 1.17 & 16.84 & 9.60 & 1.46 & 51.90 & 10.13 & 1.54 & 53.72 \\
\hline & III & 6.49 & 7.50 & 1.16 & 15.56 & 9.78 & 1.51 & 57.94 & 10.20 & 1.57 & 57.16 \\
\hline & avg & $\begin{array}{c}6.32 \pm \\
0.38 \\
\end{array}$ & $\begin{array}{c}7.36 \pm \\
0.43 \\
\end{array}$ & $\begin{array}{c}1.16 \pm \\
0.01 \\
\end{array}$ & $\begin{array}{c}16.47 \pm \\
0.79\end{array}$ & $\begin{array}{c}9.42 \pm \\
0.48 \\
\end{array}$ & $\begin{array}{c}1.49 \pm \\
0.03 \\
\end{array}$ & $\begin{array}{c}54.86 \pm \\
3.02\end{array}$ & $\begin{array}{c}9.84 \pm \\
0.56 \\
\end{array}$ & $\begin{array}{c}1.56 \pm \\
0.02 \\
\end{array}$ & $\begin{array}{c}55.78 \pm \\
1.82\end{array}$ \\
\hline \multirow[t]{4}{*}{0.1} & I & 6.50 & 9.01 & 1.39 & 38.62 & 11.45 & 1.76 & 76.15 & 14.80 & 2.28 & 127.69 \\
\hline & II & 6.80 & 9.30 & 1.37 & 36.76 & 11.70 & 1.72 & 72.06 & 15.38 & 2.26 & 126.18 \\
\hline & III & 6.24 & 9.10 & 1.46 & 45.83 & 11.10 & 1.78 & 77.88 & 15.50 & 2.48 & 148.40 \\
\hline & avg & $\begin{array}{c}6.50 \pm \\
0.28\end{array}$ & $\begin{array}{c}9.14 \pm \\
0.15\end{array}$ & $\begin{array}{c}1.40 \pm \\
0.05\end{array}$ & $\begin{array}{c}40.40 \pm \\
4.79\end{array}$ & $\begin{array}{c}11.41 \pm \\
0.30\end{array}$ & $\begin{array}{c}1.75 \pm \\
0.03\end{array}$ & $\begin{array}{c}75.36 \pm \\
3.00\end{array}$ & $\begin{array}{c}15.23 \pm \\
0.37\end{array}$ & $\begin{array}{c}2.34 \pm \\
0.12\end{array}$ & $\begin{array}{c}134.09 \pm \\
12.41\end{array}$ \\
\hline
\end{tabular}

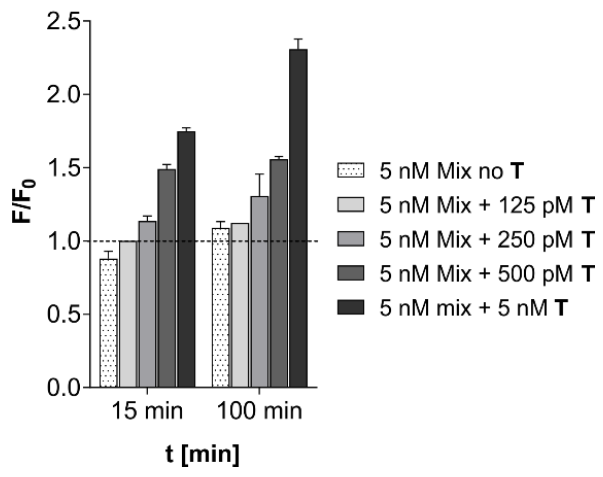

Figure S19. Signal change afforded by iMB upon photo irradiation in presence of mismatched RNA. Graphical representation of data in Table S4 
2.11 Measurements in RNA-extract and cell Lysate (HEK293WT)

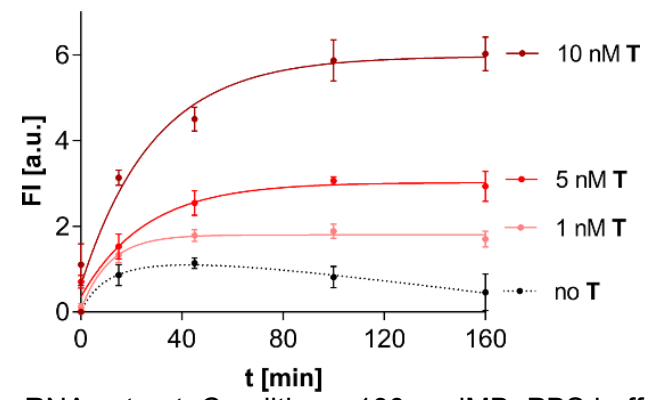

Figure S20. Signalling from the iMB in RNA extract. Conditions: $100 \mathrm{nM}$ iMB, PBS buffer $\left(10 \mathrm{mM} \mathrm{NaH}_{2} \mathrm{PO}_{4}, 100 \mathrm{~mm} \mathrm{NaCl}, 5 \mathrm{mM}\right.$ Asc., $0.001 \%$ Tween $20, \mathrm{pH}=7.4$ ), $\mathrm{T}=37^{\circ} \mathrm{C}$, irradiation at $455 \mathrm{~nm}$. The reaction was carried out in 96 well plates, $V_{\text {react: }} 150 \mu \mathrm{L}$, read-out: $100 \mu \mathrm{L}$ suprasil ultra-micro quartz cuvettes.

A)

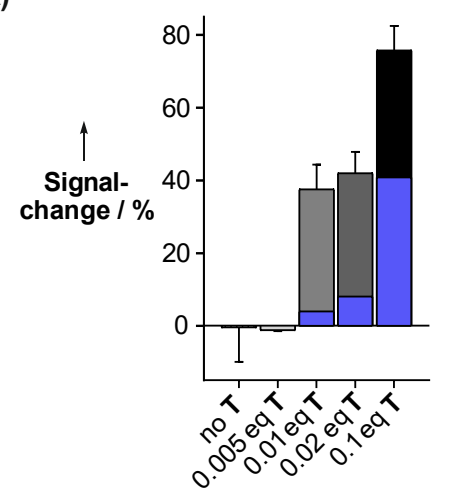

B)

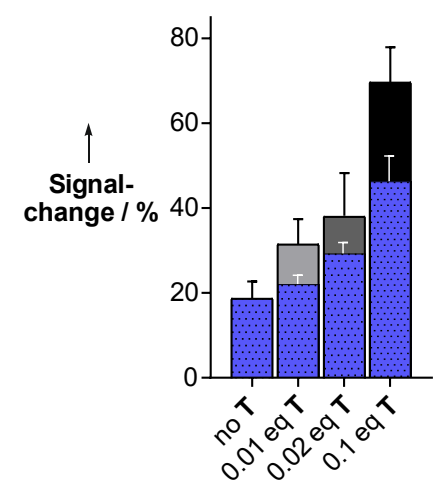

Figure S21. Signal change upon photo irradiation (15 min) of iMB in A) cell lysate or B) RNA extract spiked with indicated equivalents of target $\mathbf{T}$. The blue overlay indicates the theoretical signal change provided by a non-cleavable MB probe with similar fluorescence turn-on characteristics. Conditions: A) $50 \mathrm{nM}$ iMB in 8 vol\% lysate from 10 mio. HEK293 in PBS buffer containing 5 $\mathrm{mM} \mathrm{MgCl} 2,5 \mathrm{~mm}$ Asc., $\mathrm{pH}=7.4,37^{\circ} \mathrm{C}$. Read out in $1000 \mu \mathrm{L}$ suprasil quartz cuvettes. B) $100 \mathrm{nM}$ iMB in RNA extract (5 $\mu$ in PBS buffer, $5 \mathrm{~mm}$ Asc., $0.001 \%$ Tween $20, \mathrm{pH}=7.4$ ) at $37^{\circ} \mathrm{C}$. Read-out in $100 \mu \mathrm{L}$ suprasil ultra-micro quartz cuvettes.

Table S5. Measurements in cell lysate. Fluorescence Intensities (a.u.); c (iMB) $=50 \mathrm{nM}, \mathrm{PBS}$-buffer $\left(10 \mathrm{mM} \mathrm{NaH}_{2} \mathrm{PO}_{4}, 100 \mathrm{mM}\right.$ $\mathrm{NaCl}, 5 \mathrm{~mm}$ Asc., $5 \mathrm{mM} \mathrm{MgCl} 2, \mathrm{pH}=7.4), \mathrm{T}=37^{\circ} \mathrm{C}$, irradiation at $455 \mathrm{~nm}$.

\begin{tabular}{|c|c|c|c|c|c|c|c|c|c|c|}
\hline \multirow[t]{2}{*}{ eq $(T)$} & & \multirow{2}{*}{$\begin{array}{c}0 \text { min } \\
\text { FI / a.u. }\end{array}$} & \multicolumn{2}{|c|}{$0 \min +T$} & \multicolumn{2}{|c|}{$15 \mathrm{~min}$} & \multicolumn{2}{|c|}{$45 \mathrm{~min}$} & \multicolumn{2}{|c|}{$100 \mathrm{~min}$} \\
\hline & & & FI / a.u. & $F / F_{0}$ & FI / a.u. & $F / F_{0}$ & FI / a.u. & $F / F_{0}$ & FI / a.u. & $F / F_{0}$ \\
\hline \multirow[t]{4}{*}{0} & 1 & 4.72 & 4.57 & 0.97 & 3.84 & 0.81 & 3.80 & 0.81 & 4.50 & 0.95 \\
\hline & II & 4.65 & 4.67 & 1.00 & 5.26 & 1.13 & 5.84 & 1.26 & 6.00 & 1.29 \\
\hline & III & 5.10 & 5.10 & 1.00 & 5.30 & 1.04 & 6.10 & 1.20 & 5.90 & 1.16 \\
\hline & avg & $\begin{array}{c}4.82 \\
\pm 0.24 \\
\end{array}$ & $\begin{array}{c}4.78 \\
\pm 0.28\end{array}$ & $\begin{array}{c}1.00 \\
\pm 0.02\end{array}$ & $\begin{array}{c}4.80 \\
\pm 0.28 \\
\end{array}$ & $\begin{array}{c}1.00 \\
\pm 0.16 \\
\end{array}$ & $\begin{array}{c}5.25 \\
\pm 1.26 \\
\end{array}$ & $\begin{array}{c}1.09 \\
\pm 0.24 \\
\end{array}$ & $\begin{array}{c}5.47 \\
\pm 0.84 \\
\end{array}$ & $\begin{array}{r}1.14 \\
\pm 0.17 \\
\end{array}$ \\
\hline \multirow[t]{4}{*}{0.005} & 1 & 4.94 & 5.20 & 1.05 & 4.88 & 0.99 & 5.30 & 1.07 & 5.40 & 1.09 \\
\hline & II & 4.57 & 4.94 & 1.08 & 4.50 & 0.98 & 4.83 & 1.06 & 4.99 & 1.09 \\
\hline & III & 4.74 & 5.05 & 1.07 & 4.69 & 0.99 & 5.07 & 1.07 & 5.21 & 1.10 \\
\hline & avg & $\begin{array}{c}4.75 \\
\pm 0.19 \\
\end{array}$ & $4.69 \pm 0.19$ & $\begin{array}{c}1.07 \pm \\
0.01\end{array}$ & $\begin{array}{c}4.69 \pm \\
0.19\end{array}$ & $\begin{array}{c}0.99 \\
\pm 0.01 \\
\end{array}$ & $\begin{array}{c}5.07 \\
\pm 0.24 \\
\end{array}$ & $\begin{array}{c}1.07 \\
\pm 0.01 \\
\end{array}$ & $\begin{array}{c}5.20 \\
\pm 0.21 \\
\end{array}$ & $\begin{array}{r}1.09 \\
\pm 0.01 \\
\end{array}$ \\
\hline \multirow[t]{3}{*}{0.01} & 1 & 5.49 & 6.02 & 1.10 & 7.43 & 1.35 & 7.53 & 1.37 & 6.60 & 1.20 \\
\hline & II & 4.94 & 5.54 & 1.12 & 7.17 & 1.45 & 6.96 & 1.41 & 5.97 & 1.21 \\
\hline & III & 4.97 & 5.55 & 1.12 & 6.57 & 1.32 & 6.76 & 1.36 & 6.40 & 1.29 \\
\hline
\end{tabular}




\begin{tabular}{|c|c|c|c|c|c|c|c|c|c|c|}
\hline \multirow[t]{2}{*}{ eq $(T)$} & & \multirow{2}{*}{$\begin{array}{c}0 \text { min } \\
\text { FI / a.u. }\end{array}$} & \multicolumn{2}{|c|}{$0 \min +T$} & \multicolumn{2}{|c|}{$15 \mathrm{~min}$} & \multicolumn{2}{|c|}{$45 \mathrm{~min}$} & \multicolumn{2}{|c|}{$100 \mathrm{~min}$} \\
\hline & & & FI/ a.u. & $F / F_{0}$ & FI / a.u. & $F / F_{0}$ & FI / a.u. & $F / F_{0}$ & FI / a.u. & $F / F_{0}$ \\
\hline & avg & $\begin{array}{c}5.13 \\
\pm 0.31 \\
\end{array}$ & $\begin{array}{c}5.70 \\
\pm 0.27 \\
\end{array}$ & $\begin{array}{c}1.11 \\
\pm 0.01\end{array}$ & $\begin{array}{c}7.06 \\
\pm 0.44 \\
\end{array}$ & $\begin{array}{r}1.38 \\
\pm 0.07 \\
\end{array}$ & $\begin{array}{c}7.08 \\
\pm 0.40 \\
\end{array}$ & $\begin{array}{r}1.38 \\
\pm 0.03 \\
\end{array}$ & $\begin{array}{c}6.23 \\
\pm 0.32 \\
\end{array}$ & $\begin{array}{r}1.23 \\
\pm 0.05 \\
\end{array}$ \\
\hline \multirow[t]{4}{*}{0.02} & I & 4.83 & 5.65 & 1.17 & 7.18 & 1.49 & 7.30 & 1.51 & 7.00 & 1.45 \\
\hline & II & 5.29 & 5.88 & 1.11 & 7.30 & 1.38 & 7.30 & .138 & 6.70 & 1.27 \\
\hline & III & 5.49 & 6.41 & 1.17 & 7.64 & 1.39 & 8.05 & 1.47 & 8.22 & 1.50 \\
\hline & avg & $\begin{array}{c}5.20 \\
\pm 3.30\end{array}$ & $\begin{array}{c}5.98 \\
\pm 0.39\end{array}$ & $\begin{array}{c}1.14 \\
\pm 0.03\end{array}$ & $\begin{array}{c}7.37 \\
\pm 0.24\end{array}$ & $\begin{array}{c}1.42 \\
\pm 0.06\end{array}$ & $\begin{array}{c}7.55 \\
\pm 0.43\end{array}$ & $\begin{array}{r}1.45 \\
\pm 0.07\end{array}$ & $\begin{array}{c}7.31 \\
\pm 0.81\end{array}$ & $\begin{array}{r}1.40 \\
\pm 0.12\end{array}$ \\
\hline \multirow[t]{4}{*}{0.1} & 1 & 5.61 & 8.02 & 1.43 & 9.43 & 1.68 & 9.88 & 1.76 & 10.26 & 1.83 \\
\hline & II & 5.34 & 7.90 & 1.48 & 9.55 & 1.79 & 9.66 & 1.81 & 9.70 & 1.82 \\
\hline & III & 5.36 & 8.00 & 1.49 & 9.66 & 1.80 & 11.05 & 2.06 & 12.27 & 2.29 \\
\hline & avg & $\begin{array}{c}5.44 \\
\pm 0.15\end{array}$ & $\begin{array}{c}7.97 \\
\pm 0.06\end{array}$ & $\begin{array}{c}1.47 \\
\pm 0.03\end{array}$ & $\begin{array}{c}9.55 \\
\pm 0.12\end{array}$ & $\begin{array}{c}1.76 \\
\pm 0.07\end{array}$ & $\begin{array}{r}10.20 \\
\pm 0.75\end{array}$ & $\begin{array}{c}1.88 \\
\pm 0.16\end{array}$ & $\begin{array}{c}10.74 \\
\pm 1.35\end{array}$ & $\begin{array}{r}1.98 \\
\pm 0.27\end{array}$ \\
\hline
\end{tabular}

\section{References}

[1] S. Kalhor-Monfared, C. Beauvineau, D. Scherman, C. Girard, Eur. J. Med. Chem. 2016, 122, $436-441$

[2] J. R. Kramer, T. J. Deming, Biomacromolecules 2012, 13, 1719-1723. 
